\title{
空港舗装アセットマネジメントのための ハイブリッド型地盤沈下モデル
}

\author{
下村泰造 ${ }^{1}$ 小 小濱健吾 ${ }^{2} \cdot$ 貝戸清之 ${ }^{3} \cdot$ 小林潔司 ${ }^{4}$ \\ 1正会員大成建設株式会社 国際支店 土木部土木技術部技術室 ( ₹ 163-6006 新宿区西新宿 6-8-1) \\ Email:taizo@ce.taisei.co.jp \\ 2学生会員 京都大学大学院工学研究科都市社会工学専攻 ( ⿳ ㇒ 615-8540 京都市西京区京都大学桂) \\ E-mail:k.obama@psa.mbox.media.kyoto-u.ac.jp \\ 3 正会員 大阪大学特任講師 大学院工学研究科グローバル若手研究者フロンティア研究拠点 (テ 565-0871 吹田市山田丘 2-1) \\ E-mail:kaito@ga.eng.osaka-u.ac.jp \\ 4フェロー会員＼cjkstart京都大学教授 経営管理大学院経営管理講座 ( T 606-8501 京都市左京区吉田本町) \\ E-mail:kkoba@psa.mbox.media.kyoto-u.ac.jp
}

\begin{abstract}
空港施設のアセットマネジメントにおいて, 地盤沈下予測は重要な課題となる. 設計・施工段階では, 地盤 条件に多大な不確実性が介在するために, 沈下過程を確定的に予測することは困難である。本研究では, 不同 沈下を考慮した 1 次元圧密モデルを用いて, 地盤沈下過程に関するサンプルパスを作成するとともに, サンプル パスを荷重平均した混合地盤沈下モデルを作成する．空港の供用開始後，地盤沈下量を継続的にモニタリング することにより，混合地盤沈下モデルを MCMC (マルコフ連鎖モンテカルロ) 法を用いてベイズ更新するハイ ブリッド型地盤沈下モデルを提案する. 最後に, 実際の空港舗装を対象とした適用事例を通して, 提案手法の 妥当性を検証し，地盤沈下予測モデルとしての適用可能性と実用化に向けた課題を明らかにした.
\end{abstract}

Key Words : hybrid ground consolidation model, airport facilities, MCMC, asset management

\section{1.はじめに}

わが国では人工島や埋め立て地に空港が建設される 場合が少なくない.このような海上空港では, 地盤の不 同沈下により，空港舗装が損傷を受ける可能性がある. 地盤沈下の進行により, 空港舗装の勾配に関する性能 規定が満足されない場合, コンクリート舗装の大規模 補修が必要となる。このため, 空港舗装のアセットマ ネジメント戦略を決定する上で, 将来に発生する地盤 沈下を予測することは重要な課題となる.

軟弱地盤を対象として, 圧密理論を用いた地盤沈下 予測モデルが開発されている1)-5)。しかし，現実の地 盤条件には多くの不確実性が介在し, 地盤沈下過程を 確定的に予測することは極めて困難である。このため, 地盤条件を表す土質定数を確率変数として取り扱い, 不 同沈下を考慮した 1 次元圧密モデルを用いて地盤沈下 過程を確率的に予測する方法5)が提案されている.これ らの確率的地盤沈下モデルでは, モンテカルロシミュ レーションにより土質定数を生成し, それに対応した 地盤沈下過程のサンプルパスを発生することになる.

本研究では, 統計的な地盤沈下モデル (混合地盤沈 下モデルと呼ぶ) を, 確率的地盤沈下モデルを用いて求 めたサンプルパスの荷重和として表現する。その上で, 空港建設後, 地盤沈下のモニタリング情報を活用し, サ
ンプルパスの重み係数を逐次ベイズ更新するようなハ イブリッド型地盤沈下モデルを提案する. この方法に より，モニタリング情報を用いて地盤沈下過程の予測 精度を逐次向上できる. 混合地盤沈下モデルの推計精 度は, サンプルパスの発生方法やその推計精度に依存 している．混合地盤沈下モデルの推計精度を議論する 場合, ベイズ更新の根拠となったサンプルパスの発生 方法や現象再現性に関する検証が必要となる.

以上の問題意識の下に, 本研究では海上空港を対象 としたハイブリッド型地盤沈下モデルを提案する. 以 下, 2. では本研究の基本的な考え方を整理し，3.では, 圧密理論を用いて地盤沈下過程に関するサンプルパス を発生させる. 4. では, サンプルパスを用いて混合地 盤沈下モデルを作成し， 5. でベイズ更新モデルを提案 する. 6. で数値計算事例を紹介寸る.

\section{2. 本研究の基本的立場}

\section{(1) 従来の研究概要}

空港舗装のアセットマネジメントに関しては, 米国 において既に実績があり, オクラホマ空港におけるコ ンクリート舗装を対象とした舗装マネジメントシステ ム6)やFAA (Federal Aviation Administration) が提案 している舗装マネジメントシステム7)等の事例が存在 
する．両事例とも，経年的に蓄積された，十分な空港舗 装の劣化データをもとに, 空港舗装の劣化状態を表す PCI (Pavement Condition Index) を用いた劣化曲線を 最小二乗法を用いて推計する手法を採用している。し かし, 劣化過程には多大な不確実性が介在するために, 劣化曲線の推計精度は必ずしも良好ではない. 一方, 劣 化過程の不確実性を考慮した統計的劣化モデルとして, マルコフ連鎖モデルがあげられる，マルコフ連鎖モデ ルでは, 対象とする施設の健全度を, 複数の離散的な レーティング指標で表現し, 健全度間の推移確率をマ ルコフ推移確率で表現する. さらに，マルコフ推移確 率を，多段階指数八ザードモデルを用いて推計する方 法8)-11) も提案されている. しかし, 統計的劣化モデル は, モデルを推計するために対象とする施設の劣化過 程に関するデータの蓄積が必要となる.

アメリカ合衆国で開発された空港舗装マネジメント システムは, いずれも舗装地盤の安定性を前提として 開発されたものである.しかし，わが国では，空港が人 工島もしくは海岸埋立地に立地している場合が少なく ない.このような海上空港の維持管理においては, 空 港地盤の沈下が重大な影響を及ぼすことになる。した がって, 空港舗装マネジメントにおいては, 地盤沈下 量の予測を考慮した維持補修政策の検討が必要となる. 空港地盤の沈下過程を予測するために, 圧密理論を用 いた地盤沈下モデルが提案されている。しかし，地盤 条件には多大な不確実性が介在するため, 地盤沈下過 程を確定的に予測することは困難である。また，初期 施工状態や材料物性值の持つばらつき等, 地盤沈下モ デルで記述できない要因や，モデルの信頼性等による 不確実性も介在する。このため, 現実に生起した地盤 沈下状態が, 地盤沈下モデルにより推計された設計值 と一致する保証はない。

本研究では, まず空港コンクリート舗装の初期設計 段階を想定し，圧密理論に基づいた地盤沈下モデル5)を 用いて，地盤沈下過程の経年的予測を試みる。ここで, 特に近年建設が増加している海上空港を対象とすると, 地盤条件に介在する不確実性を考慮することが重要と なる，そこで，地盤パラメータをランダムに与えるこ とにより, 舖装劣化過程のサンプルパスを発生させる ような確率的 1 次元圧密モデルを採用寸る. その上で, サンプルパスの背後にある統計的な規則性を, 混合地 盤沈下モデルを用いて表現する。つぎに, 空港供用後 の期間に着目するとともに, 空港コンクリート舗装の 維持・管理過程で得られた地盤沈下情報に基づいて, 混 合地盤沈下モデルをべイズ更新させるという方法論を 提案する. このように, 本研究で提案する地盤沈下モ デルは, 力学的予測モデルと統計的予測モデルを合成 したハイブリッド型モデルである。このようなハイブ
リッド型地盤沈下モデルに関する研究は, 筆者等の知 る限り, 本研究がはじめての試みである.

なお，本研究で採用する確率的 1 次元圧密モデルの 詳細に関しては参考文献12)に譲るが，本稿では読者の 便宜を図るために，その概要について説明しておく．さ らに, 本研究で対象とする地盤沈下予測の結果は, コ ンクリート舗装の疲労破壞解析のための入力情報とな る. 地盤沈下予測, 疲労破壊解析を用いた舗装劣化予 測モデルに関しても参考文献12)を参照して欲しい. 筆 者等は, 最終的には舖装劣化予測全体を包摂したよう なハイブリッド型劣化予測モデルの開発を目的として いるが, 本原稿では, 舗装劣化予測において重要な役 割を演じることになる地盤沈下予測に焦点を絞り，八 イブリッド型地盤沈下モデルを提案している.

\section{(2) ハイブリッド型地盤沈下モデル}

対象とする期間を, 空港が供用される時点より以前 の期間と, 供用開始後の期間に分割し, 前者を設計段 階, 後者を運営段階と定義する. 設計段階では, 空港 地盤の沈下過程に関するモニタリング情報は存在しな い.したがって, 1 次モデル (確率的 1 次元圧密モデル) を用いて, メッシュごとの地盤沈下量の経年予測を行 うことが課題となる. 空港管理者は, 設計段階で必要 なボーリング調査を実施し, 地盤条件に関するデータ を獲得する．ボーリング調査により獲得するデータは, 地盤条件に関寸る部分情報であり, 完全情報ではない. このため, 地盤沈下過程を確定的には予測できない. し たがって, 設計段階では, 地盤沈下に関する複数のシ ナリオを設定するとともに, 各メッシュの地盤沈下過 程に関するサンプルパスを獲得する。 その上で, サン プル情報に基づいて，地盤沈下過程の統計的規則性を 2 次モデルを用いて表現する. 2 次モデルにより, 劣化過 程の確率的な分布を表現することが可能となる，つぎ に, 運営段階を考える. 空港の供用開始時点から, 空港 管理者は，各メッシュの地盤沈下量を継続的にモニタ リングする. 空港管理者は, 地盤沈下量に関するモニ タリング情報に基づいて，2次モデルをベイズ更新し， 3 次モデルを作成する. 以上の 3 つのサブモデルの関倸 を図-1に整理している. 本研究で提案する地盤沈下予 測モデルは，1）地盤沈下過程のサンプルパスを発生す る確率的 1 次元圧密モデル (1 次モデル), 2) 1 次モデル で生成したサンプルパスの統計的規則性を表現する混 合地盤沈下モデル (2次モデル), 3) 時間の経過にした がって獲得される新しいモニタリング情報を用いて 2 次 モデルをベイズ更新する 3 次モデル，で構成される複合 的な予測モデル (以下, ハイブリッド型地盤沈下モデル と呼ぶ) になっている.

本研究では, 空港地盤の沈下過程を, 地盤の不同沈 


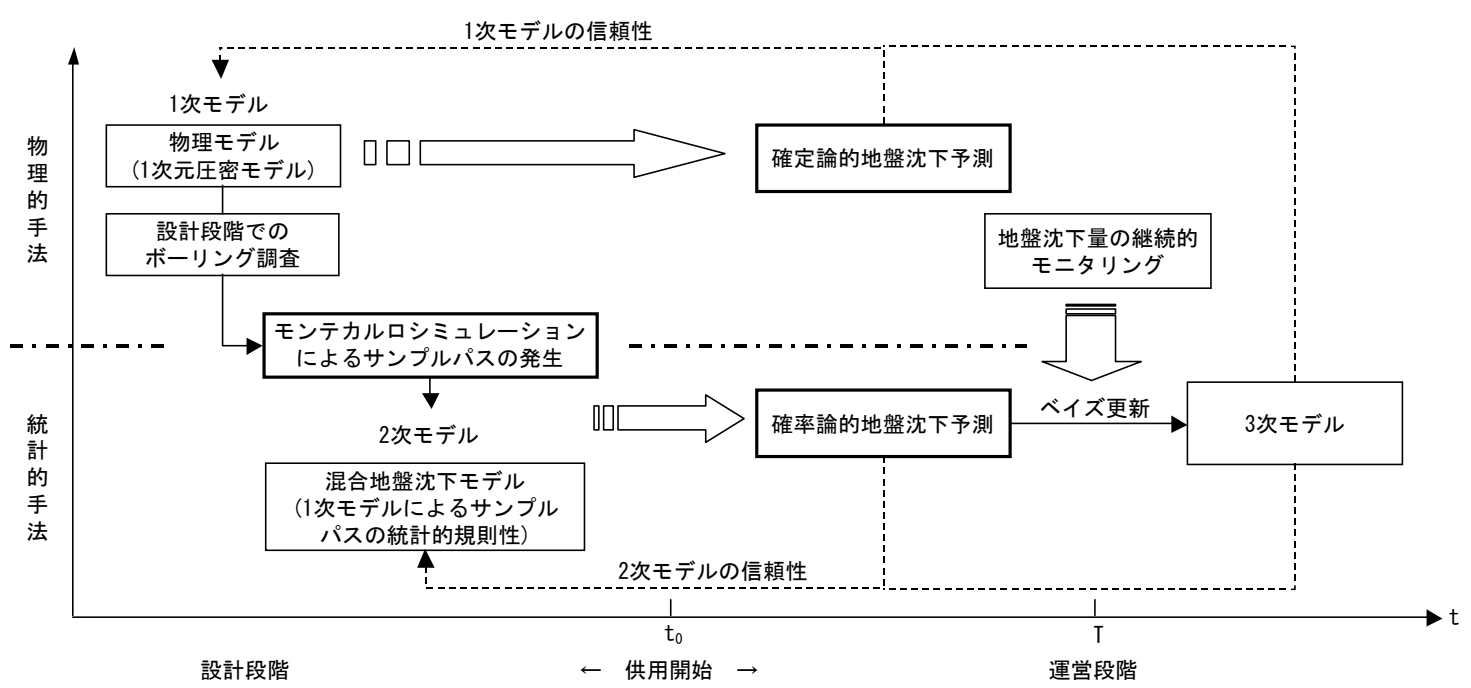

図-1ハイブリッド型地盤沈下モデルの構成

下過程を考慮した確率的 1 次元圧密モデルを用いて表 現する。そのために，対象とする空港地盤を平面メッ シュに分割するとともに, 各平面メッシュに対して垂 直方向にもメッシュ分割した 3 次元地盤モデルを用いる (図-2参照)。1次モデルを用いることにより, 各平面 メッシュごとに, 地盤沈下量の経年的変化を予測するこ とができる。しかし, 地盤条件には多くの不確実性が 介在する.このため, 地盤条件をランダムに変化させ た 1 次元圧密モデルを用いて, 多数の地盤沈下シナリオ を発生させることとする. 乱数発生により各 3 次元メッ シュの地盤条件を確定する。このように各メッシュの 地盤条件を設定すれば，1次モデルを用いて各平面メッ シュの経年的な地盤沈下過程を予測することができる. このようにして求めた地盤沈下過程は, 乱数発生によ り求めた地盤条件シナリオに対して求めた沈下過程の 1つのサンプル (以下, サンプルパスと呼ぶ) を意味し ている.

地盤条件シナリオをランダム発生させることにより， それぞれ平面メッシュごとに複数のサンプルパスを求め ることができる．空港舗装の設計や維持補修計画を立 案するためには，1次モデルを用いて作成した膨大なサ ンプルパスの情報を集約化することが必要である。もつ とも簡単な方法は, 1 次モデルで求めたサンプルパスを 平均化した期待值パスを用いる方法である。期待值パ スは簡便であるが，1次モデルで求めた膨大な情報を， 十分に活用できていないという限界がある。そこで，本 研究では 1 次モデルで求めたサンプルパスに対して重み 係数を割り当て, 地盤沈下過程をサンプルパスの荷重 平均で表現したような混合地盤沈下モデル (2 次モデル) を定式化する。設計段階では, 現実の地盤沈下過程を

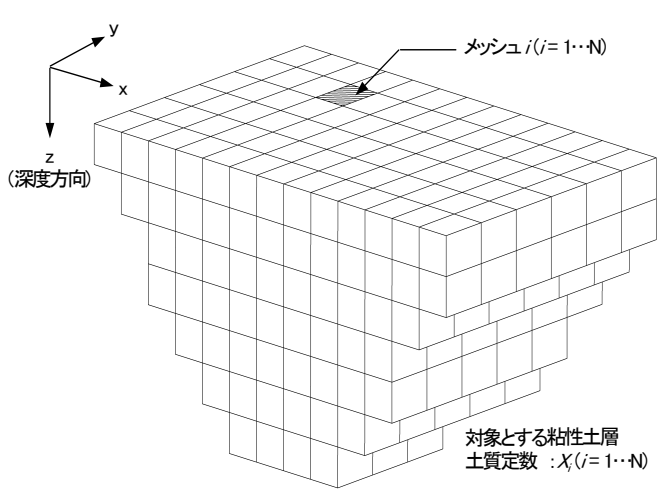

図-2 地盤のモデル化

観測できないため，2次モデルを統計的に推計すること は不可能である.したがって, 各サンプルパスの確か さに関する理論的・経験的な追加情報が存在しなけれ ば，各サンプルパスに対する重みを等しく取り扱わざ るを得ない. すなわち, 地盤沈下過程は, サンプルパ スを平均化した期待值パスとして定義される.しかし， 空港が供用された後は, 地盤沈下過程に関するモニタ リング情報が獲得できる。モニタリング情報を活用し, 2 次モデルを逐次ベイズ更新し, 地盤沈下過程の予測精 度を向上することが課題となる。このように，モニタ リング情報を用いてベイズ更新されたモデルを 3 次モデ ルと呼ぶ.

\section{(3) ベイズ更新スキーム}

空港舗装マネジメントにおいては, 地盤沈下過程を 継続的にモニタリングし, 設計段階で予測した地盤沈 


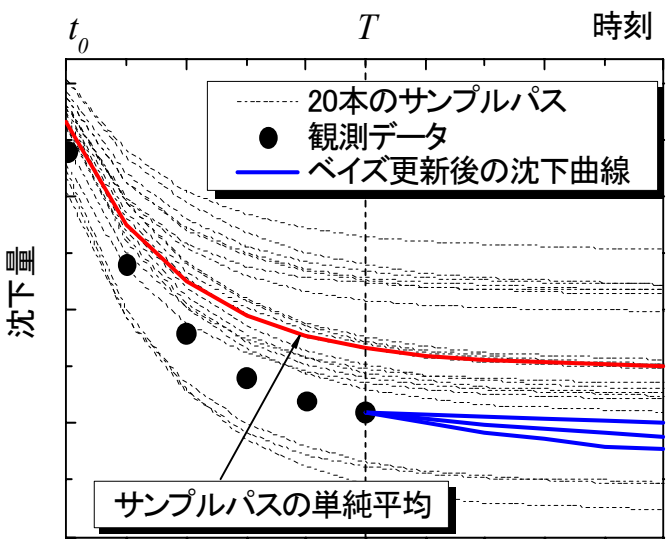

図-3混合地盤沈下モデルのベイズ更新

下過程を再評価し，必要であれば維持補修戦略の見直 しを図ることが求められる。いま，図-3に示すように， 空港供用時点 $t_{0}$ から一定期間が経過し, 現在時点 $T$ に 到達したと考える. 設計段階では, 確率 1 次元圧密モデ ルを用いて，地盤沈下過程を予測する．図中の破線は， ある平面メッシュをとりあげ, メッシュの地盤沈下量の 経年変化を予測した結果を示している．図中には土質 定数を変化させた 20 個の計算シナリオに対して求めた 地盤沈下過程のサンプルパスを示している.さらに, 図 中の太い赤線は, これらのサンプルパスの単純平均に より求めた期待值パスを示している. 空港供用開始後, 各メッシュの地盤沈下過程のモニタリングを継続した と考える. 同図には, 供用開始時点 $t_{0}$ から, 現在時点 $T$ に至るまでに観測された地盤沈下量をの印でプロット している.この例では, 地盤沈下量の実測值が，太線 で示された期待值パスよりも下方に位置している。し たがって，期待值パスを用いて地盤沈下予測した場合， 現実の沈下量を過小評価することとなる.

混合地盤沈下モデルは，サンプルパスに対して重み 係数を割り当て, サンプルパスの荷重平均を求めるこ とによって獲得できる，さらに，重み心゙クトルがある 事前分布に従って分布すると考える. 初期時点におい ては，地盤沈下に関するモニタリング情報は利用可能 でない，したがって，すべてのサンプルパスに対して， 等しい重みが割り当てられる. しかし，モニタリング 情報が獲得できれば，地盤沈下量の観測值に近いサン プルパスに対して，より大きい重みが割り当てられる ようになる。 その結果，重み係数の分布範囲をより狭 い範囲に限定することが可能となる．図-3には，現在 時点 $T$ までのモニタリング情報を用いてベイズ更新し た混合地盤沈下モデルを用いて, 現在時点 $T$ 以降の地 盤沈下過程を予測したサンプルパスを太い青線で示し ている.1次モデルで求めたサンプルパスの散らばりと
比較して, ベイズ更新後のサンプルパスは狭い範囲に 収束しており, 混合地盤沈下モデルの予測精度が向上 していることが理解できる.

\section{(4) 混合地盤沈下モデルの推計精度}

混合地盤沈下モデルは，1次モデルによる予測結果に 基づいて統計的に再構成したものである。このように 作成した混合地盤沈下モデルの推計精度は，1) サンプ ルパスを発生した 1 次モデルの信頼性，2) 2 次モデルが 1 次モデルのデータ発生メカニズムを十分な精度で近似 しているから゙うかに依存している，本研究では，前者 を 1 次モデルの信頼性問題, 後者を 2 次モデルの信頼性 問題と呼ぶこととする.

空港舗装マネジメントでは，地盤沈下過程を継続的 に観測することにより 2 次モデルの推計精度の向上を図 ることが求められる。しかし，2 次モデルをべイズ更新 したとしても, それで1次モデルの信頼性問題が解消し たわけではない.1次モデルの効用は, 地盤沈下現象を 力学モデルとして表現できる点にある．地盤沈下予測 結果に誤差が発生した場合，それが設計段階に想定し ていた範囲の中にある誤差であるかどうかを評価する ことが重要な課題となる. 混合地盤沈下モデルの統計 的信頼性を分析することにより，ハイブリッド型地盤沈 下モデルの予測誤差が，1次モデルが生成したサンプル データにより想定される予測誤差の範囲の中に納まる かどうかを検討することが可能となる．もちろん，こ のような統計的信頼性の検討を行っても，それにより 1 次モデルの信頼性が確認されたわけではない，せいぜ いのところ「1次モデルを用いて，地盤沈下現象を近似 的に表現できている」という判断情報を獲得したにす ぎない，地盤沈下過程の実績が，当初想定した誤差の 範囲を逸脱していると判断される場合には，1次モデル の信頼性を疑うべきであり，圧密理論を用いた地盤沈 下モデルの再検討が必要となることは言うまでもない.

\section{3. 地盤沈下モデル (1 次モデル)}

\section{(1) モデル化の前提条件}

空港管理者がカレンダー時刻 $\tau_{0}$ に空港施設を新たに 建設し, それ以降の時点にわたって空港コンクリート 舖装を管理する問題を考える. カレンダー時刻 $\tau_{0}$ を初 期時点 $t=0$ とする離散的時間軸 $t=0,1,2, \cdots$ を導入 する. 離散的時間間隔として，1年間を想定する. 離散 軸上の各点 $t$ を時点と呼ぶ。時点 $t$ において生じる地盤 沈下現象に対して，空港コンクリート舗装を管理する 際には，とりわけ地盤の不同沈下現象に着目寸る必要 がある，空港用地は平面的な広がりを持ち，特に海上 あるいは，臨海部の空港においては，造成地盤を構成 
する地盤物性に大きなばらつきが内在していることが 指摘されている，そこで，地盤物性のばらつきによる 不同沈下量を評価することが空港コンクリート舗装を 管理する上で重要になる，地盤物性のばらつきを考慮 した不同沈下シミュレーションモデルは，これまでに もいくつかの空港における不同沈下予測に利用されて いる，本研究においても，実務において実績のある土 田・小野5)の不同沈下モデルを用いて，地盤沈下のサン プルパスを作成する.

なお，長期的な圧密現象を考慮するとき，過剩間隙水 圧の消散に伴って生じる Terzarghi の 1 次圧密理論に従 わない 2 次圧密による影響が無視できない場合がある. 2 次圧密は主に粘土骨格の応力・ひずみ関係が非線形的 な性質を持つことが原因と考えられ，構造組織の転移 が原因であると考えられている．2 次圧密を考慮したモ デルとしては, Yoshikuni ら 13)の弾粘性圧密理論等が ある.しかし, 本研究の実証分析でとりあげる H空港 の場合, 既存施設部分において 2 次圧密による問題が発 生しておらず，入札時点における設計図書においても 2 次圧密に関する検討の必要性が指示されていない。し たがって, 本研究では 2 次圧密を考慮せずに議論を進め る.しかし，このことは本質的な問題ではなく，本研 究で提案するハイブリッド型地盤沈下予測モデルを作 成する方法論は，2次圧密を考慮した場合にも同様に適 用することが可能である。むしろ，モニタリング情報 を用いて, 2 次圧密を考慮しないことの妥当性を常に検 証することが重要である.このような 1 次モデルの信頼 性に関する検討問題に関しては6. (5) で言及する.

\section{(2) 地盤モデルの構成}

土田・小野による不同沈下モデル5) (以下，土田モデ ルと称する) は, 軟弱地盤を埋立てた場合のように, 圧 密沈下が大きく, せん断による沈下を無視しうるよう な地盤を対象とした不同沈下予測モデルである. 本モ デルの詳細については, 参考文献5)に譲るが, 読者の理 解を深めるために，モンテカルロシミュレーションの 基本構成について簡単に説明する.

モデル地盤を平面的なメッシュに分割し，それぞれ のメッシュごとに独立して沈下が生じると仮定する。ま た, 深度方向における地盤条件の不均一性を考慮するた めに，鉛直方向に対して図-2に示したような地盤メッ シュ分割を設定する，その上で，地盤を 3 次元ブロック を用いてメッシュ分割するとともに, 各ブロックにおけ る土質定数が，ある確率分布に従って分布すると仮定す る. その際，ブロック間の土質定数の空間的相関を考慮 する. 各ブロックの土質定数を確率分布からランダムに サンプリングする. その上で, 平面メッシュにおけける地 盤沈下量を 1 次元圧密理論を用いて予測する. 沈下量計
表-1 確率的 1 次元圧密モデルに用いる土質定数

\begin{tabular}{c|c|c}
\hline 圧密係数 & $c_{v}$ & 対数正規分布 \\
\hline 圧縮指数 & $C_{c}$ & 正規分布 \\
\hline 圧密降伏応力 & $p_{c}$ & 正規分布 \\
\hline 初期間隙比 & $e_{0}$ & 正規分布 \\
\hline
\end{tabular}

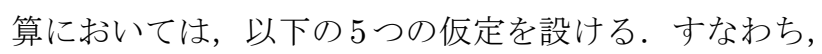
1) 1 次元圧密方程式を用い, 圧密沈下は各平面メッシュ ごとに独立に発生する．2) 各 3 次元ブロックごとに載 荷重とそれに対する沈下量を算定し，その重㸚合わせ により各平面メッシュの沈下量を求める. 3) 最終沈下 量の計算に $e-\log p$ 曲線を用いる. 4) 平面メッシュご とに深さ方向に多層地盤となるが，圧密度の計算には 換算層厚法を用いる. 5) 地中応力の計算には, 地盤を 弾性体としてブシネスクの式を用いる。 さらに，モン テカルロシミュレーションにより, 対象地盤を構成す るブロック内の土質定数をランダムに変化させた計算 ケースを設定し, 対象地域全体の地盤沈下過程に関す るサンプルパスを多数発生する. 表-1 1 , 確率的 1 次 元圧密モデルにおいて考慮する土質定数と分布関数を 示している.

一般的な土層モデルにおいては, 地盤内の土質特性 は水平方向, 鉛直方向ともほぼ連続的に変化している と考えられるが, 海上空港などの埋立て地盤において は, 埋立て土の土質物性のばらつきは少なくない。こ のため, 各平面メッシュの地盤沈下量の間に差異が生 じることにより, 地盤の不同沈下が発生する可能性が 大きい. 土田モデルでは, 地盤の水平方向の相関性を, 土質定数の空間的自己相関係数

$$
\tau_{i j}=\exp \left(-r_{i j}^{2} / b^{2}\right)
$$

を用いて評価する．ただし， $\tau_{i j}$ : メッシュ $i, j$ 間の空間 的自己相関係数, $r_{i j}$ : メッシュ $i, j$ 間の距離, $b$ : 相関距 離である. 相関距離 $b$ は, 単位距離当たりの空間的自己 相関性の強さを表すパラメータであり, $b$ の值が大きい ほど広い範囲において空間的相関が大きいことを意味 している。一方鉛直方向には代表地点で実施したボー リング調査結果に基づいて土質定数を設定する.

鉛直方向の地表面からの深さに着目寸る. 特に, 同 一の鉛直方向レベルに属する平面メッシュをとりあげ る. 対象地盤の一定深度を構成する $N$ 個の平面メッシュ $i(i=1, \cdots, N)$ の土質定数を $X_{i}(i=1, \cdots, N)$ で表す. このとき, 各ブロックの土質定数間の空間的相関構造 
を表す分散・共分散行列を

$$
\boldsymbol{C}_{x}=\left(\begin{array}{ccc}
\operatorname{Var}\left[X_{1}\right] & \cdots & \operatorname{cov}\left[X_{1}, X_{N}\right] \\
\operatorname{cov}\left[X_{2}, X_{1}\right] & \cdots & \operatorname{cov}\left[X_{2}, X_{N}\right] \\
\cdot & & \cdot \\
\cdot & & \cdot \\
\operatorname{cov}\left[X_{N}, X_{1}\right] & \cdots & \operatorname{Var}\left[X_{N}\right]
\end{array}\right)
$$

と定義する. この行列の各要素は空間的自己相関係数 $\tau_{i j}$ を用いれば

$$
\operatorname{cov}\left[X_{i}, X_{j}\right]=\sigma^{2} \tau_{i j}
$$

と特定化できる.ただし， $\sigma^{2}=\operatorname{Var}\left[X_{i}\right](i=1, \cdots, N)$ は, 土質定数の分散を表す. 分散・共分散行列 (2) は, 正值対称行列であるため対角下半行列 $C$ を用いてコレ スキ一分解

$$
C_{x}=C C^{\prime}
$$

が可能である.ただし, 記号ノは転置操作を表す.また, 対角下半行列 $\boldsymbol{C}$ は

$$
\boldsymbol{C}=\left(\begin{array}{cccc}
C_{11} & \cdots & \cdots & 0 \\
C_{21} & C_{22} & \cdots & \vdots \\
\vdots & \vdots & \ddots & \vdots \\
C_{N 1} & C_{N 2} & \cdots & C_{N N}
\end{array}\right)
$$

と表される5)。ここで, 各メッシュの土質定数をランダ 么発生させるために $n$ 個の正規乱数 $\boldsymbol{a}=\left(a_{1}, \cdots, a_{N}\right)^{\prime}$ を 発生させる. ただし, $a_{i}$ は平均 0 , 分散 1 の標準正規分布 $N(0,1)$ から抽出した值である.さらに, 各メッシュにお ける土質定数 $X$ の期待值ベクトルを $\boldsymbol{\mu}_{x}=\left(\mu_{x}^{1}, \cdots, \mu_{x}^{N}\right)^{\prime}$ と表す. この時, 正規乱数サンプルaに対して土質定数 サンプルベクトル $\boldsymbol{X} を$

$$
\boldsymbol{X}=\boldsymbol{\mu}_{x}+\boldsymbol{C a}
$$

と表すことができる5).

\section{（3）地盤沈下サンプルパスの発生}

1 次元圧密理論を用いて, 地盤沈下過程に関するサン プルパスを発生させる. 1 次元圧密沈下モデルの詳細に 関しては，参考文献 13) に譲ることとする.ここでは, 読者の便宜を図るために，その内容を簡単に紹介して おく.いま, 荷重が一定であると考え, Terzaghiの 1 次 元線形弾性圧密理論 14$)$ を用いれば，上面排水という境 界条件の下で，初期時刻 $t_{0}$ から時間 $t$ が経過した時点の 地盤沈下量 $s$ は

$$
s=s_{f}\left\{1-\sum_{n=0}^{\infty} \frac{2}{\alpha_{n}^{2}} \exp \left(-\frac{\alpha_{n}^{2} c_{v}}{\bar{H}^{2}} t\right)\right\}
$$

と表せる.ただし， $\bar{H}$ は粘土層圧， $c_{v}$ は圧密係数， $\alpha_{n}=$ $\pi(2 n+1) / 2$ である. $s_{f}$ は 1 次元圧密での最終圧密沈下 量であり, $e-\log p$ 法を用いて,

$$
s_{f}=\bar{H} \frac{\Delta e}{1+e_{0}}
$$

と表せる．ただし， $e_{0}$ は初期間隙比， $\Delta e$ は間隙比の変 化である. 載荷荷重を与えれば, 圧縮指数 $C_{c}$, 圧密降 伏応力 $p_{c}$, 初期間隙比 $\Delta p$ に規定される $e-\log p$ 曲線を 用いて間隙比の変化 $\Delta e$ を求めることができる. 本研究 で用いる $e-\log p$ 曲線は, 応力が圧密降伏応力を超過 した塑性領域における圧密過程も考慮している.さら に, $e-\log p$ 曲線を解析的に取り扱うために奥村・土田 による近似式 ${ }^{3)}$ を用いる。本近似式は，1次式と放物線 を用いて $e-\log p$ 曲線を近似しており, 弾性領域, 塑 性領域を識別するパラメータとして圧密降伏応力 $p_{c}$ が 採用されている。一方, 圧密度は圧密係数 $c_{v}$ に依存す る.したがって，これらの土質定数を，表-1に示すよ うにランダムに変化させることにより, 種々の地盤沈 下曲線を表現することが可能となる.

1 次モデルでは，すべての 3 次元ブロックに対して, 表-1に示す土質定数を, それぞれ同時にランダム発生 させる.このように，すべてのブロックに対して，モ ンテカルロシミュレーションにより土質定数を発生さ せた結果を, 以下では計算シナリオと呼ぶこととする. 発生した計算シナリオに対して, 各ブロックごとに, 初 期時点からの経過時間に対応する地盤沈下量を式 (7)を 用いて算定する. さらに, 各平面メッシュに対して, そ れと対応する鉛直方向の地盤ブロックの沈下量を集計 することにより, 当該の平面メッシュの地盤沈下量を 求めることができる。このようにして, 計算シナリオ のそれぞれに対して, 各平面メッシュごとに, 初期時 点からの経過時間に対応した地盤沈下量を求めること ができる。このような初期時点からの経過時間と沈下 量との関係を, 本研究では地盤沈下過程のサンプルパ スと呼ぶ。したがって, 計算シナリオのそれぞれに対 して, す心゙ての平面メッシュにおけるサンプルパスを 発生することが可能となる。

\section{4. 混合地盤沈下モデル (2 次モデル)}

\section{(1) 2 次モデルの目的}

1 次モデルを用いることにより, 各平面メッシュごと に複数個の地盤沈下過程に関するサンプルパスを発生 することができる. すなわち, 各サンプルパスは, ラン ダムに発生させた土質定数を与件として, 地盤沈下過 程をシミュレートした結果を表している. 地盤条件に は不確実性が介在するために, 現実に観測される地盤 沈下過程がある特定のサンプルパスに一致する保証は ない. 本節では, 現実の地盤沈下過程を, 1 次モデルで 求めたサンプルパスの荷重和で表現するような混合地 盤沈下モデルを用いて表現する。前述したように，期 待值パスはすべてのサンプルパスの期待值を求めたも のであり，すべてのサンプルパスに等しいウェイトをつ 
けたような混合地盤沈下モデルの特殊事例に他ならな い. 混合地盤沈下モデル (2次モデル) を用いて, サン プルパスの背後にある確率的構造を表現することが可 能である.さらに， 2 次モデルを作成することにより， 1) 空港供用後に観測される地盤沈下量に関するモニタ リング情報を用いて, 地盤沈下モデルのベイズ更新が 容易になる．2) 地盤沈下モデルの予測精度に関する統 計的検定が可能になるという利点がある。

\section{(2) 混合地盤沈下モデルの定式化}

1 次モデルで求めたサンプルパス $k=1, \cdots, K$ は, 各 メッシュの時点 $t$ における地盤沈下量を表現している. 平面メッシュ $i(i=1, \cdots, N)$ のサンプルパス $k$ サおけ る時点 $t(t=0, \cdots, T)$ の地盤沈下量を $f_{i}(t, k)$ と表す. 混合地盤沈下モデルは 1 次モデルで発生したサンプルパ スの荷重和として定義される．各サンプルパスに割り 付けられる重み係数が一意的に決定されるためには混 合地盤沈下モデルを構成するサンプルパスが互いに独 立でなければならない。ここでは $K$ 個の独立なサンプ ルが得られたと考える. 混合地盤沈下モデルはサンプ ルパスの線形結合

$$
y_{i}^{t}=\sum_{k=1}^{K} \omega_{i}(k) f_{i}(t, k)+\varepsilon_{i}
$$

として表現できる.ここに， $\omega_{i}(k)$ は，サンプルパス $k$ に対して割り当てられた重みであり,

$$
\sum_{k=1}^{K} \omega_{i}(k)=1(i=1, \cdots, N)
$$

が成立する，ここで，平面メッシュiの重みベクトルを $\boldsymbol{\omega}_{i}=\left(\omega_{i}(1), \cdots, \omega_{i}(K)\right)$ と表す. 重みベクトル $\boldsymbol{\omega}_{i}$ は, 制 約条件 $(10)$ を満足するような確率変数である.つぎに, $\varepsilon_{i}$ は, 測定誤差を表す確率変数であり, それぞれ独立に 1 次元正規分布 $N\left(0, \sigma_{i}^{2}\right)$ に従うと仮定する. 各平面メッ シュの確率誤差項の間に空間的な相関関係が存在する 可能性がある. しかし, 本研究の適用事例では平面メッ シュ数が 528 個であり, 確率誤差項の空間相関を考慮し ようとすれば $528 \times 528=268,324$ 次元の分散・共分散 行列を考慮する必要があり, 計算負荷が膨大になる。こ のため, 実用上の操作性を確保するため, 本研究では 混合地盤沈下モデルの確率誤差項の空間相関を考慮し ないこととする.

\section{（3）地盤沈下量の確率的予測}

混合地盤沈下モデル $(9)$ の重み行列 $\boldsymbol{\omega}_{i}$ と確率誤差項 $\varepsilon_{i}$ は確率変数である.これらの確率変数の值を特定化す れば，具体的な地盤沈下パスを得ることができる.こ こで, $\boldsymbol{\omega}_{i}$ の事前確率密度関数が, ディリクレ分布に従
うと仮定する。ディリクレ分布の確率密度関数は,

$$
\begin{aligned}
& D\left(\boldsymbol{\omega}_{i} \mid \boldsymbol{\alpha}^{(0)}\right)=\Psi\left(\boldsymbol{\alpha}^{(0)}\right) \prod_{k=1}^{K}\left\{\omega_{i}(k)\right\}^{\alpha_{k}^{(0)}-1} \\
& \Psi\left(\boldsymbol{\alpha}^{(0)}\right)=\frac{\Gamma\left(\sum_{k=1}^{K} \alpha_{k}^{(0)}\right)}{\prod_{k=1}^{K} \Gamma\left(\alpha_{k}^{(0)}\right)}
\end{aligned}
$$

で与えられる。ただし， $\Gamma(\cdot)$ はガンマ関数であり， $\boldsymbol{\alpha}^{(0)}=\left(\alpha_{1}^{(0)}, \cdots, \alpha_{K}^{(0)}\right)$ は初期データにおける定数パラ メータベクトルである. 設計段階では, 地盤沈下過程 に関する先験的情報 ${ }^{15)}$ として, 1次モデルの計算結果 (サンプルパス) のみが利用可能である. サンプルパス を用いたディリクレ分布のパラメータの設定方法に関 しては，のちに6.(3) で言及する.つぎに， $\phi_{i}=\sigma_{i}^{-2}$ とおき, $\phi_{i}$ の事前確率密度関数が, ガンマ分布に従う と仮定する. すなわち, $\phi_{i} \sim \mathcal{G}\left(\beta^{(0)}, \gamma^{(0)}\right)$ であり, ガ ンマ分布の確率密度関数は,

$$
\begin{aligned}
& g\left(\phi_{i} \mid \beta^{(0)}, \gamma^{(0)}\right) \\
& \quad=\frac{\left(\gamma^{(0)}\right)^{\beta^{(0)}}}{\Gamma\left(\beta^{(0)}\right)} \phi_{i}^{\beta^{(0)}-1} \exp \left(-\gamma^{(0)} \phi_{i}\right)
\end{aligned}
$$

で与えられる.ただし， $\beta^{(0)}, \gamma^{(0)}$ は初期データにおけ る定数パラメータである. この時, メッシュ $i$ の時点 $t$ における地盤沈下量 $y_{i}^{t}$ 事後確率密度関数 $\pi\left(y_{i}^{t}\right)$ は,

$$
\begin{aligned}
& \pi\left(y_{i}^{t}\right) \propto \int \cdots \int \phi_{i}^{\beta^{(0)}-1 / 2} \prod_{k=1}^{K} \omega_{i}(k)^{\alpha_{k}^{(0)}-1} \\
& \exp \left[-\phi_{i}\left\{\gamma^{(0)}+\frac{1}{2}\left(y_{i}^{t}-\sum_{k=1}^{K} \omega_{i}(k) f_{i}(t, k)\right)^{2}\right\}\right] \\
& d \phi_{i} d \omega_{i}(1) \cdots d \omega_{i}(K-1)
\end{aligned}
$$

と表される.ただし, $\omega_{i}(K)=1-\sum_{k=1}^{K-1} \omega_{i}(k)$ であ る. 事後確率密度関数 $\pi\left(y_{i}^{t}\right)$ を解析的に求めることは困 難であり, モンテカルロシミュレーションにより求め る. 寸なわち, $\phi_{i}, \omega_{i}(1), \cdots, \omega_{i}(K-1)$ を事前確率密度 関数 (11a),(12)よりランダムサンプリングするととも に, $y_{i}^{t}$ を正規確率密度関数 $N\left(\sum_{k=1}^{K} \omega_{i}(k) f_{i}(t, k), \phi_{i}^{-1}\right)$ よりランダム抽出することにより地盤沈下量の確率分 布を求めることができる.

\section{5. ベイズ更新モデル (3 次モデル)}

\section{(1) 混合地盤沈下モデルのベイズ更新}

混合地盤沈下モデルは, 1 次モデルで発生した地盤沈 下過程に関するサンプルパスを用いて，地盤沈下過程 に介在する統計的不確実性を表現した統計的モデルで ある．混合地盤沈下モデルには，各サンプルパスに割り 当てられた重みベクトル $\boldsymbol{\omega}_{i}$, 確率的誤差項 $\varepsilon_{i}$ という確 率変数が含まれている。初期時点においては, これら の確率変数に関する観測值が存在せず, 地盤沈下過程 の統計的性質は確率変数の事前確率密度関数 (11a), (12) 
で表現されている，空港が供用された運営段階では，各 メッシュの地盤沈下量に関するモニタリング情報が計 測される。いま，供用開始時点 (初期時点と呼ぶ) から 時間が経過し, 時点 $T$ に到達したと考える. さらに時点 $t(t=0, \cdots, T)$ におけるモニタリングにより, 地盤沈 下量に関するデータ $\overline{\boldsymbol{y}}_{i}^{0, T}=\left(\bar{y}_{i}^{0}, \cdots, \bar{y}_{i}^{T}\right)(i=1, \cdots, N)$ が獲得できたと考える。記号「」」はモニタリング情 報 (実測值) を意味している。モニタリング結果全体を ベクトル $\overline{\boldsymbol{y}}^{0, T}=\left(\overline{\boldsymbol{y}}_{1}^{0, T}, \cdots, \overline{\boldsymbol{y}}_{N}^{0, T}\right)$ と表す. ここで, ひと まず重みベクトル $\boldsymbol{\omega}_{i}$ を与件とし, 確率誤差項のみが確 率変数と考える. 確率誤差項の分散の逆数 $\phi$ も件とす る.この時, モニタリング結果 $\overline{\boldsymbol{y}}_{i}^{0, T}$ が観測される尤度は

$$
\begin{aligned}
& \mathcal{L}\left(\overline{\boldsymbol{y}}_{i}^{0, T} \mid \boldsymbol{\omega}_{i}, \phi_{i}\right) \\
& \propto \prod_{t=0}^{T} \phi_{i}^{1 / 2} \exp \left[-\frac{\phi_{i}}{2}\left\{\bar{y}_{i}^{t}-\sum_{k=1}^{K} \omega_{i}(k) f_{i}(t, k)\right\}^{2}\right]
\end{aligned}
$$

と表される。つぎに， $\boldsymbol{\omega}_{i}$ の事前確率密度関数が，ディ リクレ分布 (11a), 分散の逆数 $\phi_{i}$ がガンマ分布 $(12)$ に従 うと仮定する.

この時, $\boldsymbol{\omega}_{i}, \overline{\boldsymbol{y}}_{i}^{0, T}$ を既知とした時の $\phi_{i}$ の条件付き事 後確率密度関数 $\pi\left(\phi_{i} \mid \boldsymbol{\omega}_{i}, \overline{\boldsymbol{y}}_{i}^{0, T}\right)$ は,

$$
\begin{aligned}
& \pi\left(\phi_{i} \mid \boldsymbol{\omega}_{i}, \overline{\boldsymbol{y}}_{i}^{0, T}\right) \\
& \propto \phi_{i}^{\bar{\beta}^{(0)}-1} \exp \left(-\bar{\gamma}^{(0)} \phi_{i}\right) \\
& \bar{\beta}^{(0)}=\beta^{(0)}+\frac{T+1}{2} \\
& \bar{\gamma}^{(0)}=\gamma^{(0)}+\frac{1}{2} \sum_{t=0}^{T}\left\{\bar{y}_{i}^{t}-\sum_{k=1}^{K} \omega_{i}(k) f_{i}(t, k)\right\}^{2}
\end{aligned}
$$

と表せる.すなわち, $\pi\left(\phi_{i} \mid \boldsymbol{\omega}_{i}, \overline{\boldsymbol{y}}_{i}^{0, T}\right)$ はガンマ分布 $\mathcal{G}\left(\bar{\beta}^{(0)}, \bar{\gamma}^{(0)}\right)$ に従い， $\phi_{i}$ の標本サンプルはガンマ分布 $\mathcal{G}\left(\bar{\beta}^{(0)}, \bar{\gamma}^{(0)}\right)$ から発生させることができる.

つぎに, $\phi_{i}, \overline{\boldsymbol{y}}_{i}^{0, T}$ を既知とした $\boldsymbol{\omega}_{i}$ の条件付事後確率 密度関数 $\pi\left(\boldsymbol{\omega}_{i} \mid \phi_{i}, \overline{\boldsymbol{y}}_{i}^{0, T}\right)$ は,

$$
\begin{aligned}
& \pi\left(\boldsymbol{\omega}_{i} \mid \phi_{i}, \overline{\boldsymbol{y}}_{i}^{0, T}\right) \\
& \propto \exp \left[-\frac{\phi_{i}}{2} \sum_{t=0}^{T}\left\{\bar{y}_{i}^{t}-\sum_{k=1}^{K} \omega_{i}(k) f_{i}(t, k)\right\}^{2}\right] \\
& \prod_{k=1}^{K} \omega_{i}(k)^{\alpha_{k}^{(0)}-1}
\end{aligned}
$$

と表せる。

\section{(2) MH アルゴリズム}

式(16)に示される $\boldsymbol{\omega}_{i}$ の条件付事後確率密度関数は, 一般によく知られた分布ではない。したがって， $\boldsymbol{\omega}_{i}$ の 標本サンプルを条件付事後確率密度関数 $\pi\left(\boldsymbol{\omega}_{i} \mid \phi_{i}, \overline{\boldsymbol{y}}_{i}^{0, T}\right)$ から直接サンプリング16)することは難しい. 本研究で は，直接サンプリング法を用いない MH 法17)-19)を適
用する. $\mathrm{MH}$ 法では， $\pi\left(\boldsymbol{\omega}_{i} \mid \phi_{i}, \overline{\boldsymbol{y}}_{i}^{0, T}\right)$ を近似するような 提案分布からサンプリングを行い，それに基づいて本 来の分布からのサンプルを求めることになる20).さら に，サンプリングの効率性をあげるために，ランダム ウォークを用いる. ランダムウォーク法を用いた MH 法 自体に関しては新規性はないが，読者の便宜を図るた めに本研究の文脈に即してアルゴリズムについて簡単 に説明しておく.

はじめに，パラメータベクトル $\boldsymbol{\omega}_{i}$ の初期值を $\omega_{i}^{0}=$ $\left(\omega_{i}^{0}(1), \cdots, \omega_{i}^{0}(K)\right)$ と表す。この時, 新たな候補点 $\boldsymbol{\omega}_{i}^{\prime}$ を,

$$
\boldsymbol{\omega}_{i}^{\prime}=\boldsymbol{\omega}_{i}^{0}+\lambda \boldsymbol{\nu}
$$

により提案する.ただし，入はステップ幅の範囲を定め る定数パラメータ, $\boldsymbol{\nu}=(\nu(1), \cdots, \nu(K))$ はステップ幅 を定めるパラメータベクトルである. 候補点 $\boldsymbol{\omega}_{i}^{\prime}$ が, 制約 条件 $\sum_{k=1}^{K} \omega_{i}^{\prime}(k)=1$ を満足するために $\sum_{k=1}^{K} \nu(k)=0$ が成立しなければならない. この時, 変数変換 $\nu^{\prime}=\boldsymbol{\nu}+$ $K^{-1} \boldsymbol{I}$ にり，散がディリクレ分布に従うことになる. ただし，Iは $1 \times K$ 次の単位行列である．ステップ幅の 範囲は全ての $k$ について等しく, $\left(-\lambda K^{-1}, \lambda\left(1-K^{-1}\right)\right)$ に設置する. また, 提案分布として, 定数パラメータ ベクトル $\chi=\left(\chi_{1}, \cdots, \chi_{K}\right)$ を持つディリクレ分布を用 いて,

$$
q\left(\boldsymbol{\omega}_{i}^{0}, \boldsymbol{\omega}_{i}^{\prime} \mid \phi_{i}, \overline{\boldsymbol{y}}_{i}^{0, T}\right)=\mathcal{D}\left(\frac{\boldsymbol{\omega}_{i}^{\prime}-\boldsymbol{\omega}_{i}^{0}}{\lambda}+\frac{\boldsymbol{I}}{K} \mid \chi\right)
$$

と定義する。この提案分布は，条件

$$
q\left(\boldsymbol{\omega}_{i}^{0}, \boldsymbol{\omega}_{i}^{\prime} \mid \phi_{i}, \overline{\boldsymbol{y}}_{i}^{0, T}\right)=q\left(\boldsymbol{\omega}_{i}^{\prime}, \boldsymbol{\omega}_{i}^{0} \mid \phi_{i}, \overline{\boldsymbol{y}}_{i}^{0, T}\right)
$$

を満たしている。よって, 提案密度 $q$ は $\left(\boldsymbol{\omega}_{i}^{0}, \boldsymbol{\omega}_{i}^{\prime}\right)$ に 関して対称であるため, 新しい候補点の受容確率 $\kappa\left(\boldsymbol{\omega}_{i}^{0}, \boldsymbol{\omega}_{i}^{\prime} \mid \overline{\boldsymbol{y}}_{i}^{0, T}\right)$ を,

$$
\kappa\left(\boldsymbol{\omega}_{i}^{0}, \boldsymbol{\omega}_{i}^{\prime} \mid \overline{\boldsymbol{y}}_{i}^{0, T}\right)=\min \left\{\frac{\pi\left(\boldsymbol{\omega}_{i}^{\prime} \mid \phi_{i}^{n}, \overline{\boldsymbol{y}}_{i}^{0, T}\right)}{\pi\left(\boldsymbol{\omega}_{i}^{n} \mid \phi_{i}^{n}, \overline{\boldsymbol{y}}_{i}^{0, T}\right)}, 1\right\}
$$

と表すことができる．受容された場合には新しい候補点 に移動し，棄却された場合にはその場にとどまる. 図-4 に，MH法によるアルゴリズムをフローチャートにより 示している. MHアルゴリズムの手順は, 以下のように 整理できる.

\section{a) ステップ 1 初期值設定}

事前分布 $(11 \mathrm{a}),(12)$ のパラメータベクトル $\boldsymbol{\alpha}^{(0)}=$ $\left(\alpha_{1}^{(0)}, \cdots, \alpha_{K}^{(0)}\right), \beta^{(0)}, \gamma^{(0)}$ の值を任意に設定する.さ らに, パラメータ推計量の初期值 $\boldsymbol{\omega}_{i}^{0}=\left(\omega_{i}^{0}(1), \cdots\right.$, $\left.\omega_{i}^{0}(K)\right), \phi_{i}^{0}$ を任意に設定する. 定数パラメータ $\lambda$, 定 数パラメータベクトル $\chi$, サンプル数 $\underline{n}, \bar{n}$ を設定する. これらの初期值の影響は, MCMC 法によるシミュレー ション回数が蓄積されるにつれ, 次第に薄れていく. シ ミュレーション回数を $n=0$ とする. 


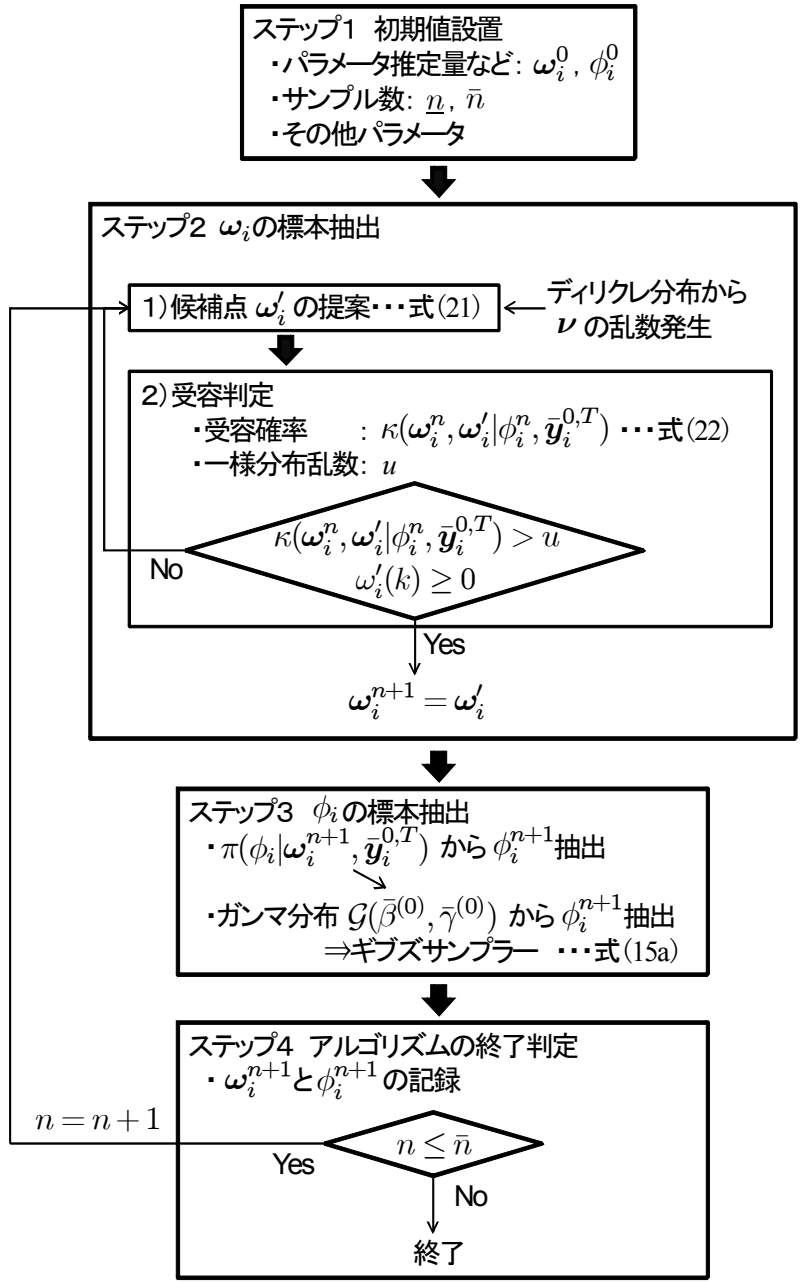

図-4ＭHアルゴリズムの概要

\section{b) ステップ 2 パラメータ推計量 $\boldsymbol{\omega}_{i}$ の標本抽出}

シミュレーション回数 $n+1$ におけるパラメータ推計量 $\boldsymbol{\omega}_{i}^{n+1}=\left(\omega_{i}^{n+1}(1), \cdots, \omega_{i}^{n+1}(K)\right)$ を次のように発生す る. ディリクレ分布に従う神を乱発生させる. ステッ プ幅を定めるパラメータベクトル $\boldsymbol{\nu} \boldsymbol{\nu}=\boldsymbol{\nu}^{\prime}-K^{-1} I$ よ り計算する。新たな候補点 $\boldsymbol{\omega}_{i}^{\prime}$ を,

$$
\boldsymbol{\omega}_{i}^{\prime}=\boldsymbol{\omega}_{i}^{n}+\lambda \boldsymbol{\nu}
$$

とする、受容確率,

$$
\kappa\left(\boldsymbol{\omega}_{i}^{n}, \boldsymbol{\omega}_{i}^{\prime} \mid \phi_{i}^{n}, \overline{\boldsymbol{y}}_{i}^{0, T}\right)=\min \left\{\frac{\pi\left(\boldsymbol{\omega}_{i}^{\prime} \mid \phi_{i}^{n}, \overline{\boldsymbol{y}}_{i}^{0, T}\right)}{\pi\left(\boldsymbol{\omega}_{i}^{n} \mid \phi_{i}^{n}, \overline{\boldsymbol{y}}_{i}^{0, T}\right)}, 1\right\}
$$

を計算する. 続いて一様分布 $u \sim U(0,1)$ を発生させ，

$$
\begin{aligned}
& \kappa\left(\boldsymbol{\omega}_{i}^{n}, \boldsymbol{\omega}_{i}^{\prime} \mid \phi_{i}^{n}, \overline{\boldsymbol{y}}_{i}^{0, T}\right)>u \\
& \omega_{i}^{\prime}(k) \geq 0(k=1, \cdots, K)
\end{aligned}
$$

の両式を同時に満たす時, $\boldsymbol{\omega}_{i}^{n+1}=\boldsymbol{\omega}_{i}^{\prime}$ としてステップ 3 一，そうでない場合はステップ 2 の1)へ戻る.

\section{c) ステップ 3 パラメータ推計量 $\phi_{i}$ の標本抽出}

$\phi_{i}^{n+1}$ を $\pi\left(\phi_{i} \mid \boldsymbol{\omega}_{i}^{n+1}, \overline{\boldsymbol{y}}_{i}^{0, T}\right)$ から発生させる. 寸なわち, $\phi_{i}^{n+1}$ をガンマ分布 $\mathcal{G}\left(\bar{\beta}^{(0)}, \bar{\gamma}^{(0)}\right)$ から乱数発生させる.

\section{d) ステップ 4 アルゴリズムの終了判定}

以上で求めたパラメータ推計量の更新值 $\boldsymbol{\omega}_{i}^{n+1}=$ $\left(\omega_{i}^{n+1}(1), \cdots, \omega_{i}^{n+1}(K)\right), \phi_{i}^{n+1}$ を記録する. $n \leq \bar{n}$ の 場合， $n=n+1$ としてステップ 2 へ戻る. そうでない 場合，アルゴリズムを終了する.

\section{(3) 事後分布に関する統計量}

MCMC 法によって得られた標本に基づいて，パラ メータベクトル $\boldsymbol{\omega}_{i}, \phi_{i}$ に関する統計的性質を分析するこ とができる21),22)，MCMC法を用いた場合，パラメー タの事後確率密度関数 $\pi\left(\boldsymbol{\omega}_{i}, \phi_{i} \mid \overline{\boldsymbol{y}}_{i}^{0, T}\right)$ を解析的な関数と して表現できず，標本を用いてノンパラメトリックに 分布関数や密度関数を表現する. いま, MH法によって 得られた標本を $\left(\boldsymbol{\omega}_{i}^{n}, \phi_{i}^{n}\right)(n=1, \cdots, \bar{n})$ と表す. この うち, 最初の $\underline{n}$ 個の標本は収束過程からの標本と考え, 標本集合から除去する. その上で，パラメータの標本 添字集合を $\mathcal{M}=\{\underline{n}+1, \cdots, \bar{n}\}$ と定義する.このとき， パラメータ $\boldsymbol{\omega}_{i}$ の同時確率分布関数 $F\left(\boldsymbol{\omega}_{i}\right)$, およびパラ メータ $\phi_{i}$ の周辺確率分布関数 $G\left(\phi_{i}\right)$ は,

$$
\begin{aligned}
& F\left(\boldsymbol{\omega}_{i}\right)=\frac{\#\left\{\boldsymbol{\omega}_{i}^{n} \leq \boldsymbol{\omega}_{i}, n \in \mathcal{M}\right\}}{\bar{n}-\underline{n}} \\
& G\left(\phi_{i}\right)=\frac{\#\left\{\phi_{i}^{n} \leq \phi_{i}, n \in \mathcal{M}\right\}}{\bar{n}-\underline{n}}
\end{aligned}
$$

と表すことができる.ただし， $\#\left\{\boldsymbol{\omega}_{i}^{n} \leq \boldsymbol{\omega}_{i}, n \in \mathcal{M}\right\}$ は 論理式 $\boldsymbol{\omega}_{i}^{n} \leq \boldsymbol{\omega}_{i}, n \in \mathcal{M}$ が成立するサンプルの総数で ある.また, パラメータ $\boldsymbol{\omega}_{i}$ の事後分布の期待值べクト ル $\tilde{\boldsymbol{\mu}}_{i}\left(\boldsymbol{\omega}_{i}\right)$, 分散・共分散行列 $\tilde{\boldsymbol{\Sigma}}_{i}\left(\boldsymbol{\omega}_{i}\right)$ は, それぞれ

$$
\begin{aligned}
& \tilde{\boldsymbol{\mu}}_{i}\left(\boldsymbol{\omega}_{i}\right)=\left(\tilde{\mu}\left(\omega_{i}(1)\right), \cdots, \tilde{\mu}\left(\omega_{i}(K)\right)\right)^{\prime} \\
& =\left(\sum_{n=\underline{n}+1}^{\bar{n}} \frac{\omega_{i}^{n}(1)}{\bar{n}-\underline{n}}, \cdots, \sum_{n=\underline{n}+1}^{\bar{n}} \frac{\omega_{i}^{n}(K)}{\bar{n}-\underline{n}}\right)^{\prime} \quad(25 \mathrm{a}) \\
& \tilde{\boldsymbol{\Sigma}}_{i}\left(\boldsymbol{\omega}_{i}\right)=\left(\begin{array}{lll}
\tilde{\zeta}^{2}\left(\omega_{i}(1)\right) & \cdots & \tilde{\zeta}\left(\omega_{i}(1) \omega_{i}(K)\right) \\
\vdots & \ddots & \vdots \\
\tilde{\zeta}\left(\omega_{i}(K) \omega_{i}(1)\right) & \cdots & \tilde{\zeta}^{2}\left(\omega_{i}(K)\right)
\end{array}\right)
\end{aligned}
$$

と表される。ただし，

$$
\begin{aligned}
& \tilde{\zeta}^{2}\left(\omega_{i}(k)\right)=\sum_{n=\underline{n}+1}^{\bar{n}} \frac{\left\{\omega_{i}^{n}(k)-\tilde{\mu}\left(\omega_{i}(k)\right)\right\}^{2}}{\bar{n}-\underline{n}} \\
& \tilde{\zeta}\left(\omega_{i}(k) \omega_{i}(l)\right) \\
& =\sum_{n=\underline{n}+1}^{n} \frac{\left\{\omega_{i}^{n}(k)-\tilde{\mu}\left(\omega_{i}(k)\right)\right\}\left\{\omega_{i}^{n}(l)-\tilde{\mu}\left(\omega_{i}(l)\right)\right\}}{\bar{n}-\underline{n}}
\end{aligned}
$$

である. パラメータ $\phi_{i}$ の事後分布の期待值 $\tilde{\mu}_{i}\left(\phi_{i}\right)$, 分散 $\tilde{\zeta}_{i}\left(\phi_{i}\right)$ は, 標本平均, 標本分散を用いて表される.すな 
わち，

$$
\begin{aligned}
\tilde{\mu}_{i}\left(\phi_{i}\right) & =\sum_{n=\underline{n}+1}^{\bar{n}} \frac{\phi_{i}^{n}}{\bar{n}-\underline{n}} \\
\tilde{\zeta}^{2}\left(\phi_{i}\right) & =\sum_{n=\underline{n}+1}^{\bar{n}} \frac{\left\{\phi_{i}^{n}-\tilde{\mu}\left(\phi_{i}\right)\right\}^{2}}{\bar{n}-\underline{n}}
\end{aligned}
$$

である。

また，MH法による標本を用いて，パラメータ $\boldsymbol{\omega}_{i}$, $\phi_{i}$, および時点 $t$ における地盤沈下量 $y_{i}(t)$ の信用区間 を定義できる．たとえば，パラメータ $\boldsymbol{\omega}_{i}, \phi_{i}$ の 100(1$2 \delta) \%$ 信用区間は, 標本順序統計量 $\left(\underline{\omega}_{i}^{\delta}(k), \bar{\omega}_{i}^{\delta}(k)\right)(k=$ $1, \cdots, K),\left(\underline{\phi}_{i}^{\delta}, \bar{\phi}_{i}^{\delta}\right)$,

$$
\begin{aligned}
& \underline{\omega}_{i}^{\delta}(k)=\arg \max _{\omega_{i}^{n^{*}}(k)} \\
& \left\{\frac{\#\left\{\omega_{i}^{n}(k) \leq \omega_{i}^{n^{*}}(k), n \in \mathcal{M}\right\}}{\bar{n}-\underline{n}} \leq \delta\right\} \\
& \bar{\omega}_{i}^{\delta}(k)=\arg \min _{\omega_{i}^{n^{*}}(k)} \\
& \left\{\frac{\#\left\{\omega_{i}^{n}(k) \geq \omega_{i}^{n^{* *}}(k), n \in \mathcal{M}\right\}}{\bar{n}-\underline{n}} \leq \delta\right\} \\
& \underline{\phi}_{i}^{\delta}=\arg \max _{\phi_{i}^{n^{*}}} \\
& \left\{\frac{\#\left\{\phi_{i}^{n} \leq \phi_{i}^{n^{*}}, n \in \mathcal{M}\right\}}{\bar{n}-\underline{n}} \leq \delta\right\} \\
& \bar{\phi}_{i}^{\delta}=\arg \min _{\phi_{i}^{n^{* *}}} \\
& \left\{\frac{\#\left\{\phi_{i}^{n} \geq \phi_{i}^{n^{* *}}, n \in \mathcal{M}\right\}}{\bar{n}-\underline{n}} \leq \delta\right\}
\end{aligned}
$$

を用いて $\underline{\omega}_{i}^{\delta}(k)<\omega_{i}(k)<\bar{\omega}_{i}^{\delta}(k), \underline{\phi}_{i}^{\delta}<\phi_{i}<\bar{\phi}_{i}^{\delta}$ と定義 できる。

\section{(4) ベイズ更新とベイズ予測}

メッシュiにおける第 $t$ 回目までのモニタリング結果 $\overline{\boldsymbol{y}}_{i}^{0, t}=\left(\bar{y}_{i}^{0}, \cdots, \bar{y}_{i}^{t}\right)$ を用いて, 混合地盤沈下モデルの未 知パラメータに関する事後分布が求まっていると考え る. その上で, 第 $t+1$ 回目から第 $t^{\prime}$ 回目までのモニタ リング結果 $\overline{\boldsymbol{y}}_{i}^{t+1, t^{\prime}}=\left(\bar{y}_{i}^{t+1}, \cdots, \bar{y}_{i}^{t^{\prime}}\right)$ を用いて, 未知パ ラメータの事後分布を更新する問題を想定する。第 1 回目のベイズ推計における未知パラメータの事後確率 密度関数を $\pi\left(\boldsymbol{\omega}_{i}, \phi_{i} \mid \overline{\boldsymbol{y}}_{i}^{0, t}\right)$ とすれば, 第 2 回目のべイズ 更新を行った後の未知パラメータの事後確率密度関数 $\pi\left(\boldsymbol{\omega}_{i}, \phi_{i} \mid \overline{\boldsymbol{y}}_{i}^{0, t^{\prime}}\right)$ は,

$$
\begin{aligned}
& \pi\left(\boldsymbol{\omega}_{i}, \phi_{i} \mid \overline{\boldsymbol{y}}_{i}^{0, t^{\prime}}\right) \propto \mathcal{L}\left(\boldsymbol{\omega}_{i}, \phi_{i} \mid \overline{\boldsymbol{y}}_{i}^{t+1, t^{\prime}}\right) \pi\left(\boldsymbol{\omega}_{i}, \phi_{i} \mid \overline{\boldsymbol{y}}_{i}^{0, t}\right) \\
& \propto \mathcal{L}\left(\boldsymbol{\omega}_{i}, \phi_{i} \mid \overline{\boldsymbol{y}}_{i}^{0, t^{\prime}}\right) \mathcal{D}\left(\boldsymbol{\omega}_{i} \mid \boldsymbol{\alpha}^{(0)}\right) g\left(\phi_{i} \mid \beta^{(0)}, \gamma^{(0)}\right)
\end{aligned}
$$

と表すことができる.ここに, $\mathcal{L}\left(\boldsymbol{\omega}_{i}, \phi_{i} \mid \overline{\boldsymbol{y}}_{i}^{0, t^{\prime}}\right)$ は, 初期 時点から第 $t^{\prime}$ 回目までのモニタリング結果をプールした データベースを用いて定義される尤度関数である。一 方, $\mathcal{D}\left(\boldsymbol{\omega}_{i} \mid \boldsymbol{\alpha}^{(0)}\right), g\left(\phi_{i} \mid \beta^{(0)}, \gamma^{(0)}\right)$ は, それぞれ第1回目 のベイズ推計時に用いた $\boldsymbol{\omega}_{i}, \phi_{i}$ の事前分布である。し
たがって，ベイズ更新後の事後分布は，

$$
\begin{aligned}
& \pi\left(\boldsymbol{\omega}_{i}, \phi_{i} \mid \overline{\boldsymbol{y}}_{i}^{0, t^{\prime}}\right) \\
& \propto \phi_{i}^{\beta^{(0)}+\left(t^{\prime}-1\right) / 2} \exp \left[-\phi_{i}\left\{\gamma^{(0)}+\frac{1}{2} \sum_{t=0}^{t^{\prime}}\left(\bar{y}_{i}^{t}-\right.\right.\right. \\
& \left.\left.\left.\sum_{k=1}^{K} \omega_{i}(k) f_{i}(t, k)\right)^{2}\right\}\right] \prod_{k=1}^{K} \omega_{i}(k)^{\alpha_{k}^{(0)}-1}
\end{aligned}
$$

となる. すなわち, 未知パラメータの事後分布を更新す るためには, 新しいモニタリング結果を追加したデー タベースに対して尤度関数を定義し, MH法により事 後分布を新しく求めることが必要となる.

初期時点 $t=0$ から時点 $t=T$ に至るまでのモニタリ ング情報 $\overline{\boldsymbol{y}}_{i}^{0, T}$ と, 混合地盤沈下モデルのパラメータの 事後分布 $\pi\left(\boldsymbol{\omega}_{i}, \phi_{i} \mid \overline{\boldsymbol{y}}_{i}^{0, T}\right)$ を与件とする. その上で, 時点 $t=T$ 以降の地盤沈下量を予測する問題を考える. 時 点 $t=T$ における平面メッシュ $i$ の地盤沈下量の実測值 (モニタリング情報) を $\bar{y}_{i}^{T}$ と表す. 一方, 時点 $t=T$ 以 降の時点 $\tilde{t}(>T)$ の地盤沈下量の時点 $t=T$ における予 測值を $\tilde{y}_{i}^{\tilde{t}}(T)$ と表す. 時間の経過に伴って地盤沈下が常 に進行すると仮定すれば,

$$
\bar{y}_{i}^{T} \leq \tilde{y}_{i}^{T \tilde{+} 1}(T) \leq \cdots \leq \tilde{y}_{i}^{T \tilde{+} n}(T) \leq \cdots
$$

が成立する．ただし， $n$ は自然数である。ここで，混合 地盤沈下モデルのパラメータ $\boldsymbol{\omega}_{i}$ を与件とする. この時, 時点 $t=T$ において地盤沈下量 $\bar{y}_{i}^{T}$ が観測されたとする ならば，混合地盤沈下モデルの予測残差 $\xi_{i}^{T}$ は

$$
\xi_{i}^{T}=\bar{y}_{i}^{T}-\sum_{k=1}^{K} \omega_{i}(k) f_{i}(T, k)
$$

と表される.さらに，重み係数 $\boldsymbol{\omega}_{i}$ を与件とすれば，時 点 $t=T$ 以降の時点 $\tilde{t}(>T)$ における地盤沈下量の時点 Tにおける予測值 $\tilde{y}_{i}^{\tilde{t}}(T)$ は, 混合地盤沈下モデル

$$
\tilde{y}_{i}^{\tilde{t}}(T)=\sum_{k=1}^{K} \omega_{i}(k) f_{i}(\tilde{t}, k)+\xi_{i}^{T}
$$

を用いて確定的に表される。

つぎに, 時点 $t=T$ までのモニタリング情報 $\overline{\boldsymbol{y}}^{0, T}$ を用いてベイズ更新されたパラメータ值 $\boldsymbol{\omega}_{i}$ の事後分布 $F\left(\boldsymbol{\omega}_{i} \mid \overline{\boldsymbol{y}}_{i}^{0, T}\right)$ は, MCMC 法を用いて式(24a)のように近 似できる，さらに，MCMC 法を用いて発生した重みサ ンプルを $\boldsymbol{\omega}_{i}^{n}(n \in \mathcal{M}, i=1, \cdots, N)$ と表す. この時, 時 点Tにおいて地盤沈下量 $\bar{y}_{i}^{T}$ を観測した場合に，それ以 降の時点 $\tilde{t}(\tilde{t}>T)$ における地盤沈下量 $\tilde{y}_{i}^{\tilde{t}}(T)$ に関する 確率分布関数 $H_{i}\left(\tilde{y}_{i} \mid \tilde{t}, \bar{y}_{i}^{T}\right)$ は

$$
H_{i}\left(\tilde{y}_{i} \mid \tilde{t}, \bar{y}_{i}^{T}\right)=\frac{\#\left\{\tilde{y}_{i}^{\tilde{t}, n}(T) \leq \tilde{y}, n \in \mathcal{M}\right\}}{\bar{n}-\underline{n}}
$$

と表される.ただし, $\tilde{y}_{i}^{\tilde{t}, n}(T)$ は, 重夕係数のサンプル 值 $\boldsymbol{\omega}_{i}^{n}$ を用いて時点 $T$ において予測した時点 $\tilde{t}(>T)$ の 
地盤沈下量の予測值であり,

$$
\begin{aligned}
& \tilde{y}_{i}^{\tilde{t}, n}(T)=\sum_{k=1}^{K} \omega_{i}^{n}(k) f_{i}(\tilde{t}, k)+\xi_{i}^{T, n} \\
& \xi_{i}^{T, n}=\bar{y}_{i}^{T}-\sum_{k=1}^{K} \omega_{i}^{n}(k) f_{i}(T, k)
\end{aligned}
$$

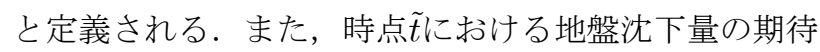
值 $E\left[\tilde{y}_{i}^{\tilde{t}}(T)\right]$ は

$$
E\left[\tilde{y}_{i}^{\tilde{t}}(T)\right]=\frac{\sum_{n=\underline{n}+1}^{\bar{n}} \omega_{i}^{n}(k) f_{i}(\tilde{t}, k)+\xi_{i}^{T, n}}{\bar{n}-\underline{n}}
$$

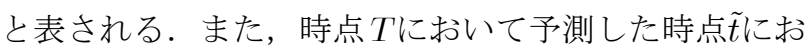
ける地盤沈下量 $\tilde{y}_{i}^{\tilde{t}}(T)$ の $100(1-2 \delta) \%$ 信用区間は, 標本 順序統計量 $\left(\underline{y}_{i}^{\tilde{t}}(\delta, T), \bar{y}_{i}^{\tilde{t}}(\delta, T)\right)$

$$
\begin{aligned}
& \underline{y}_{i}^{\tilde{t}}(\delta, T)=\arg \max _{y_{i}^{*}} \\
& \left\{\frac{\#\left\{\tilde{y}_{i}^{\tilde{t}, n}(T) \leq y_{i}^{*}, n \in \mathcal{M}\right\}}{\bar{n}-\underline{n}} \leq \delta\right\} \\
& \bar{y}_{i}^{\tilde{t}}(\delta, T)=\arg \min _{y_{i}^{* *}} \\
& \left\{\frac{\#\left\{\tilde{y}_{i}^{\tilde{t}, n}(T) \geq y_{i}^{* *}, n \in \mathcal{M}\right\}}{\bar{n}-\underline{n}} \leq \delta\right\}
\end{aligned}
$$

を用いて $\underline{y}_{i}^{\tilde{t}}(\delta, T)<\tilde{y}_{i}^{\tilde{t}}(T)<\bar{y}_{i}^{\tilde{t}}(\delta, T)$ と定義できる.

\section{6. 適用事例}

\section{(1) 適用事例の概要}

本研究では，海上空港である $\mathrm{H}$ 空港を対象としてと りあげる，同空港では，年間概称 3 万回程度の近距離国 際旅客便の就航と深夜早朝時間帯を利用した国際貨物 便就航を目的とし，エプロンを含む基本施設の他，空 港保安施設, 付帯施設, 構内道路・駐車場および緑地 の設計，施工から維持管理までを対象としたPFI事業 を実施している，中でも，エプロン部は，航空機が駐 機するエリアであり，高い耐流動性および而油性が求 められることからコンクリート舗装が適用されている. 同エプロンは，軟弱地盤上に位置しており，地盤の不 同沈下によるコンクリート舗装の疲労劣化が問題とな る。そこで，下村等 ${ }^{12)}$ は，不同沈下を考慮した疲労度 設計手法により，コンクリート舗装版の累積疲労度を 算定することにより, コンクリート舗装の劣化過程を 予測し, 維持補修管理戦略を検討する方法を提案して いる．その際，土質条件に不確実性が介在することか ら，土質定数を確率変数と考え，3. で述べた 1 次モデ ルを用いて地盤沈下過程をシミュレートしている. 地 盤沈下過程には多大な不確実性が介在するが，PFI事 業における費用リスクを可能な限り抑制するためには, 供用開始後の地盤沈下過程を継続的にモニタリングす るとともに, その結果に基づいてコンクリート舗装の
維持補修計画を継続的にアップデートしていくことが 不可欠である.このような課題を効率的に達成するた めには，モニタリング情報に基づいて地盤沈下モデル の精度を継続的に向上していくことが求められる.も とより, 本研究で提案したハイブリッド地盤沈下モデ ルは，地盤沈下量のベイズ予測を目的とするものであ るが，本モデルのアウトプットを用いて疲労度設計手 法により，コンクリート舗装版の劣化予測を行うこと が可能となる. 舗装劣化予測に関しては, 別の機会に 発表する予定である.

対象としたエリアは，H空港におけるエプロン部で あり， $825 \mathrm{~m} \times 400 \mathrm{~m}$ の範囲に及ぶ．圧密沈下の検討に際 しては, 一辺が $25 \mathrm{~m} \times 25 \mathrm{~m}$ の正方形メッシュを基本単位 とし，上記エプロン範囲を平面メッシュエリアに分割し た。また，対象となる圧密沈下層については，GL-7m 付近から GL-25m 付近に存在する沖積粘性土層および GL-25m 付近から GL-60m 付近に存在する洪積粘性 土層を対象とし，1次元圧密理論に基づいて検討を実 施した。前述した土田モデル5)では，メッシュ相互の 土質定数の相関を考慮することができる. 本検討事例 では, ボーリング調査結果より, 水平方向相関距離を $b=100 \mathrm{~m}$ とし, 鉛直方向相関距離を 4〜 $5 \mathrm{~m}$ に設定し た. 鉛直方向のメッシュ区分については同一土層であっ ても概ね $4 \mathrm{~m}$ 毎に区分し, メッシュ分割を行った。解析 にあたっては対象エリアにおいて実施した 17 本のボー リングデータおよび圧密試験結果より, 沖積粘性土層 および洪積粘性土層を深度方向に, それぞれ $\mathrm{A}_{\mathrm{c} 1} \sim \mathrm{A}_{\mathrm{c} 6}$ 層, $\mathrm{D}_{\mathrm{c} 1} \sim \mathrm{D}_{\mathrm{c} 4}$ 層の合計 10 層に区分し, 土質定数を整理 した. ここで，不同沈下を推計するにあたり，当エリア で実施したボーリングデータ数は概ね $140 \mathrm{~m}$ に 1 本の割 合であった。これは, 既往の研究5)より当該地域の地盤 定数の相関距離が 100〜 200m であったことを踏まえた ものであり，土質性状が確率的に同一とみなすことが できる範囲を選定して, ボーリングデータ数を決定し た。一方, 盛土造成による載荷荷重については, 各平 面メッシュ $i(=1, \cdots, 528)$ におけるメッシュ中心位置で の現地盤高さを設定したのち, 路床, 下層路盤, 上層 路盤の各整正時期およびエプロン舗装の舗設時期を各 平面メッシュ毎に整理し, 施工時期を想定した解析ス テップを考慮している. 具体的には対象全エリアにお いて路床の整正が終了する15ケ月後までに生じる圧密 沈下量については地盤の勾配修正が可能であることか ら, 最終沈下量から差し引くこととした. 表-2に，本 検討事例に使用した不同沈下シミュレーション用土質 定数を示す.

\section{(2) 1 次モデルによる解析結果}

3. で示した 1 次モデルにより地盤の不同沈下をシミュ 
表-2 不同沈下シミュレーション用土質定数

\begin{tabular}{l|c|c|c|c|c|c|c|c|c}
\hline & \multicolumn{2}{|c|}{$C_{c}\left(\mathrm{kN} / \mathrm{m}^{2}\right)$} & \multicolumn{3}{|c|}{$e_{0}$} & \multicolumn{2}{c}{$p_{c}\left(\mathrm{kN} / \mathrm{m}^{2}\right)$} & \multicolumn{3}{c}{$c_{v}\left(\mathrm{~cm}^{2} / \mathrm{day}\right)$} \\
\cline { 2 - 10 } & 期待值 & 標準偏差 & 期待值 & 標準偏差 & 期待值 & 変動係数 & 期待值 & $\log c_{v}$ & $\log c_{v}$ 標準偏差 \\
\hline $\mathrm{A}_{\mathrm{c} 1 \text { 層 }}$ & 0.45 & 0.07 & 1.34 & 0.17 & 70 & 0.36 & 993 & -4.26 & 0.29 \\
\hline $\mathrm{A}_{\mathrm{c} 2}$ 層 & 0.41 & 0.06 & 1.21 & 0.11 & 59 & 0.33 & 1025 & -4.15 & 0.09 \\
\hline $\mathrm{A}_{\mathrm{c} 3}$ 層 & 0.73 & 0.11 & 1.84 & 0.22 & 95 & 0.49 & 759 & -4.40 & 0.33 \\
\hline $\mathrm{A}_{\mathrm{c} 4}$ 層 & 0.87 & 0.08 & 2.09 & 0.15 & 90 & 0.39 & 787 & -4.32 & 0.23 \\
\hline $\mathrm{A}_{\mathrm{c} 5}$ 層 & 0.74 & 0.21 & 1.91 & 0.39 & 99 & 0.44 & 1103 & -4.20 & 0.26 \\
\hline $\mathrm{A}_{\mathrm{c} 6}$ 層 & 0.31 & 0.12 & 1.17 & 0.22 & 139 & 0.08 & 3435 & -3.63 & 0.09 \\
\hline $\mathrm{D}_{\mathrm{c} 1 \text { 層 }}$ & 0.44 & 0.13 & 1.32 & 0.30 & 174 & 0.71 & 1680 & -3.95 & 0.14 \\
\hline $\mathrm{D}_{\mathrm{c} 2}$ 層 & 0.57 & 0.16 & 1.54 & 0.27 & 144 & 0.67 & 1945 & -4.01 & 0.34 \\
\hline $\mathrm{D}_{\mathrm{c} 3 \text { 層 }}$ & 0.66 & 0.12 & 1.58 & 0.19 & 135 & 0.66 & 1000 & -4.27 & 0.29 \\
\hline $\mathrm{D}_{\mathrm{c} 4}$ 層 & 0.70 & 0.25 & 1.64 & 0.67 & 186 & 0.65 & 1002 & -4.23 & 1.66 \\
\hline
\end{tabular}

注) $\mathrm{A}_{\mathrm{c} 1}-\mathrm{A}_{\mathrm{c} 6}$ については, 沖積粘性土層をボーリング結果および室内圧密試験結果より得られた土質性状の区分から深度方向 に6 層に分類し，上層より下層に向けてナンバリングを行った。同様に, $\mathrm{D}_{\mathrm{c} 1}-\mathrm{D}_{\mathrm{c} 4}$ につても, 洪積粘性土層の土質性状の区 分により，上層より下層に向けてナンバリングした結果を表す.

レーションする．各ブロックに対して土質定数を表-1 に示した確率分布からランダムに発生させる．具体的 には，鉛直方向に区分した各圧密対象層の土質定数に 対して, 表-2に示した期待值, 標準偏差および変動係 数より, 圧縮指数 $C_{c}$, 初期間隙比 $e_{0}$ および, 圧密降伏 応力 $p_{c}$ については正規分布, 圧密係数 $c_{v}$ については対 数正規分布から発生させた。 なお，これらの期待值と 分散は, 代表的な平面メッシュで実施したボーリング 調査結果に基づいて設定した.すべての 3 次元ブロック に対して，土質定数を $3 .(2)$ で示したモンテカルロシ ミュレーションによりランダム発生させた.すべての 3 次元ブロックに対して発生させた土質定数の組を, 計 算シナリオと呼ぶこととする，さらに，各計算シナリ オに対して, 1次モデルを用いて, 対象とするすべての 平面メッシュの地盤沈下過程を求めた.

解析に先立って，モンテカルロシミュレーションの 試行回数を表-3に示すように, 20 回と 50 回の 2 通り設 定した. 両者の平均沈下量, 平均不同沈下量の期待值 と最大不同沈下量の期待值を比較して, 試行回数が解 析結果に及ぼす影響が少ないことを確認した上で, 最 終的に試行回数を 20 回と決定した. ここで, 平均不同 沈下率とは, 全沈下量の平均值に対する不同沈下量の 比であり, 最大不同沈下率とは, 全沈下量の平均值に対 する最大不同沈下量の比を表す. 不同沈下シミュレー ション結果の 1 例を図-5 に示す. 同図は, 例として選 定した平面メッシュ $i=73$ における経年的な地盤沈下 量に対する 20 本のサンプルパスを示している. 対象と して選択した平面メッシュは現地盤高さ $\mathrm{AP}+3.0 \mathrm{~m}$ に対 し計画地盤高さが $\mathrm{AP}+6.0 \mathrm{~m}$ であり，エリア内で盛土高 が大きい箇所に該当する.1 次モデルによるシミュレー ションの結果, 図-6 に示寸ように 30 年後の期待值パス 沈下量が $35.75 \mathrm{~cm}$ となり, 対象地盤の中で沈下量がもっ とも大きくなることが予測されている．横軸は $\mathrm{H}$ 空港
表-3 試行回数が計算結果に及ぼす影響

\begin{tabular}{c|c|c} 
表-3 試行回数が計萛結果䏛数 & 20 回 & 50 回 \\
\hline 平均沈下量 $(\mathrm{cm})$ & 23.6 & 23.7 \\
\hline 平均不同沈下率の期待值 & 0.16 & 0.16 \\
\hline 最大不同沈下率の期待值 & 0.70 & 0.71 \\
\hline
\end{tabular}

の供用開始時点を 0 としているが，路盤整正後から供用 開始時点に至るまでの期間内に, 寸でに地盤沈下が発 生していることがわかる. また, 図-5 中の 20 本のサン プルパスを比較すると，土質定数シナリオによって地盤 沈下量が大きく変化することが理解できる．実際に 30 年後の平均沈下量は $35.75 \mathrm{~cm}$ であり, 分散は $30.66 \mathrm{~cm}^{2}$ と大きくなっている.一方, いずれのサンプルパスで も, 時間の経過とともに地盤沈下過程は収束している.

\section{(3) 2 次モデルの作成}

1 次モデルで得られた 20 本のサンプルパス (図-5 参 照) を用いて, 混合地盤沈下モデル (2 次モデル) を推計 する. 1次モデルで求めたサンプルパスは, 互いに強い 相関関係にある，例えば，図-5に示した 20 本のサンプ ルパス間の相関係数は, 最低でも 0.976 であった. した がって, 多重共線性の問題を避けるため, 20 本のサン プルパスの中で契約終了時点において, 予測沈下量の 上限值と下限值を規定する 2 本のサンプルパスを用いて 混合地盤沈下モデルを推計することとした．以下，もっ とも上方に位置するパスをサンプルパス $\alpha$, 下方に位置 するパスをサンプルパス $\beta$ と呼ぶ. いずれのメッシュで も，契約期間全体を通じて， $2 つ$ サンプルパス $\alpha, \beta$ が予測沈下量の上限值と下限值を規定していることを 付記しておく.すなわち, サンプルパス $\alpha, \beta$ を選択す ることにより，2本のサンプルパスに挟まれた区間を可 能な限り拡大寸ることが可能であり， 2 次モデル， 3 次 


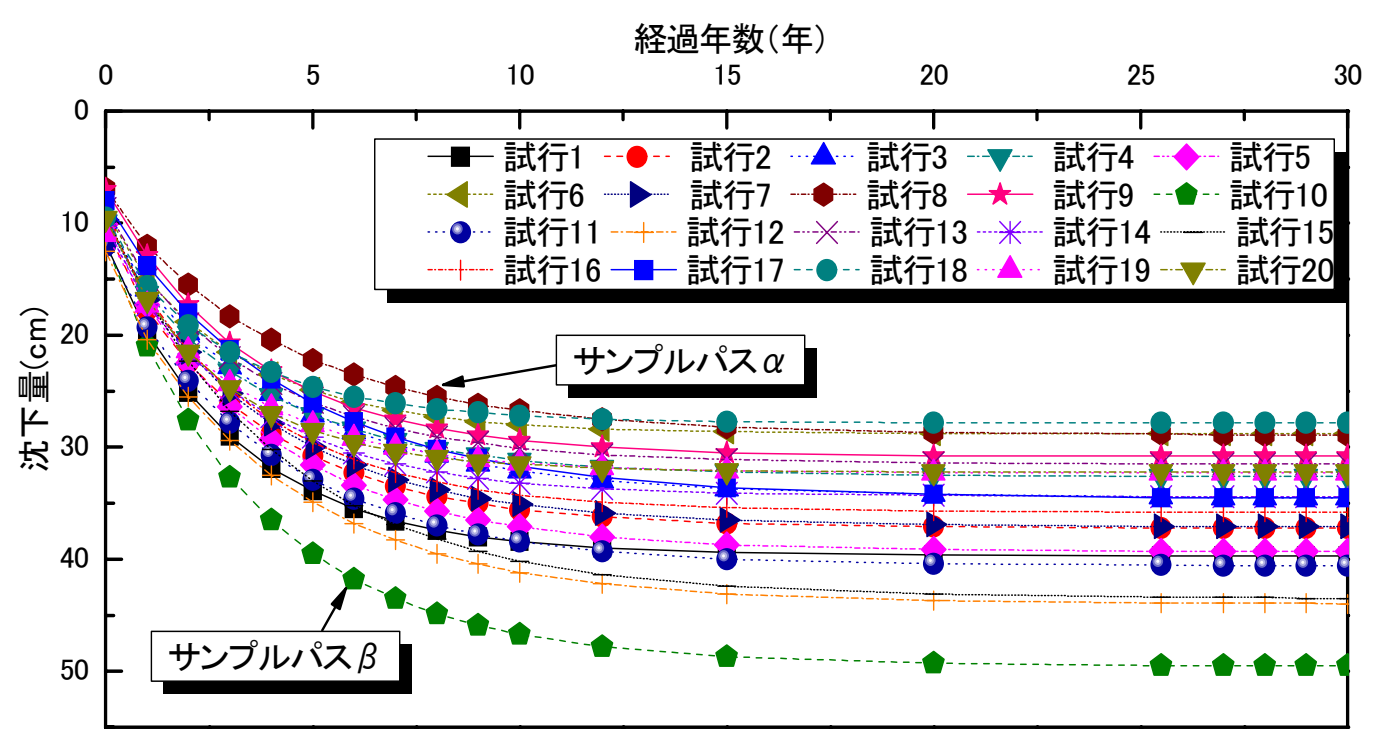

図-5 不同沈下シミュレーション結果の例

モデルを作成できる範囲を最大化している．図-6には， 20 本のサンプルパスを単純平均して求めた期待值パス を示している，同図には，混合地盤沈下モデルを作成 するために用いる 2 本のサンプルパスを平均化した結 果 (サンプル平均パスと呼ぶ) も併記している. 当然の ことながら，ここで求めたパスは，20本のサンプルパ スを単純平均した期待值パスと一致しない。したがっ て, 時刻 $t$ におけるメッシュ $i$ の地盤沈下量 $y_{i}^{t}$ を予測す るために, 混合地盤沈下モデルによる期待パスと, サ ンプル平均パスとの乘離を可能な限り小さくするよう に, 混合地盤沈下モデルの重多係数 $\omega_{i}(k)(k=1,2)$ を 補正する必要がある。いま, 20 本のサンプルパスを用 いた期待值パスの時刻 $t$ におけるメッシュ $i$ の地盤沈下 予測量を $\tilde{y}_{i}^{t}$ と表す. この時, $\omega_{i}(k)(k=1,2)$ が,

$$
\min _{\omega_{i}(1), \omega_{i}(2)}\left\{\tilde{y}_{i}^{t}-\sum_{k=1}^{2} \omega_{i}(k) f_{i}(t, k)\right\}^{2}
$$

を満たすような值をとると, 期待值パスとサンプル平 均パスの乘離は限りなく小さくなる.ただし, $f_{i}(t, k)$ は, 混合地盤沈下モデルを作成するために選択した (1 次モデルで求めた) サンプルパスである.いま, 式(38) によって定められる時刻 $t$ における重みベクトル $\boldsymbol{\omega}_{i}$ を, $\tilde{\omega}_{i}^{t}$ と表す. さらに, 混合地盤沈下モデルの重みベクト $\boldsymbol{U} \boldsymbol{\omega}_{i}$ の事前確率密度関数が式(11a)のディレクレ分布と して特定化できると考える. メッシュ $i$ の時刻 $t$ におけ る地盤沈下量 $y_{i}^{t}$ の事後確率密度関数 $\pi\left(y_{i}^{t}\right)$ は, 式 (13) に 示すように解析的に求めることが困難であるため, モ ンテカルロシミュレーションによって求める必要があ る. そのため, 重みベクトル $\boldsymbol{\omega}_{i}$ は, 式(11a)に示寸ディ リクレ分布からランダム抽出される。したがって, 期

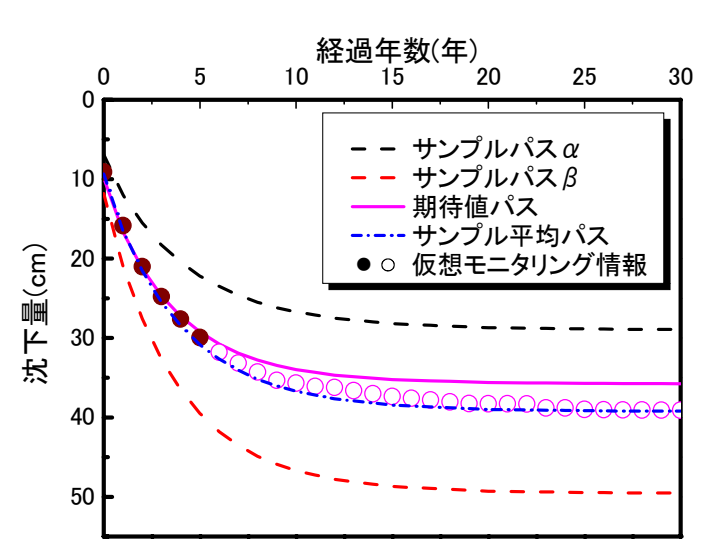

図-6＼cjkstart仮想モニタリング情報とサンプルパス

待值パスとサンプル平均パスの乘離を限りなく小さく するために，近似的に

$$
E\left[\omega_{i}(k)\right] \approx \tilde{\omega}_{i}^{t}(k)(k=1,2)
$$

が成立するようにディリクレ分布のパラメータベクト ルを定める。いま，ディリクレ分布において， $\omega_{i}(k)$ の 期待值は,

$$
\begin{aligned}
E\left[\omega_{i}(k)\right] & =\frac{\alpha_{k}^{(0)}}{\sum_{k=1}^{2} \alpha_{k}^{(0)}} \\
(k & =1,2)
\end{aligned}
$$




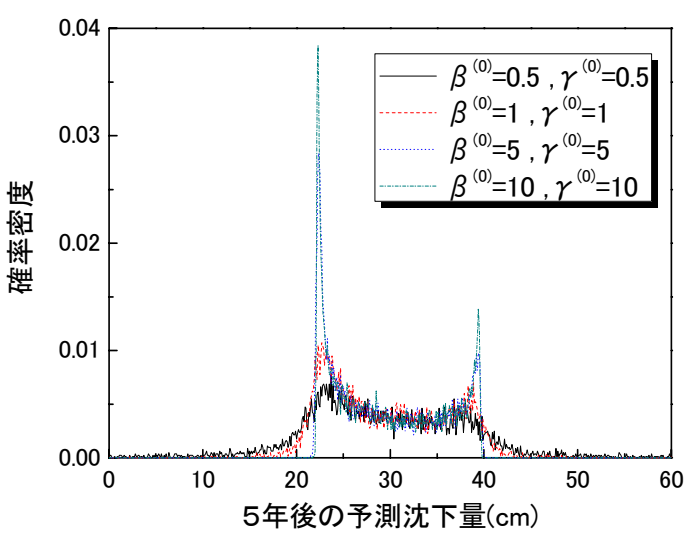

図-7 5 年後の予測沈下量の分布

と表せる.したがって, ディリクレ分布の初期パラメー タ $\alpha_{k}^{(0)}(k=1,2)$ を,

$$
\tilde{\omega}_{i}^{t}(k)=\frac{\alpha_{k}^{(0)}}{\sum_{k=1}^{2} \alpha_{k}^{(0)}}(k=1,2)
$$

が成立するように決定する．以上で設定した混合地盤沈 下モデルを用いて，5年後の地盤沈下量 $y_{i}^{5}$ を予測する. 予測沈下量の分布は, 式 (13) に示すように, $\boldsymbol{\alpha}^{(0)}$, およ び $\phi_{i}$ の事前確率密度関数を決定することで得られる。い ま，ディリクレ分布のパラメータベクトル $\boldsymbol{\alpha}^{(0)}$ を，重み ベクトル $\tilde{\boldsymbol{\omega}}_{i}^{5}$ をもとに， $\alpha_{1}^{(0)}=0.593, \alpha_{2}^{(0)}=0.407$ と定 める. 図-7は，平面メッシュ $i=73$ をとりあげ， $\phi_{i}$ の事 前確率密度関数のパラメータ $\beta^{(0)}, \gamma^{(0)}$ の值により, 5 年 後の予測沈下量の分布がどのように変化するかを示した 結果である. 図-7に示すように, パラメータ $\beta^{(0)}, \gamma^{(0)}$ の值を増大させると, 予測沈下量はより狭い範囲に分 布することがわかる。一方， $\beta^{(0)}, \gamma^{(0)}$ の值を減少させる と, 予測沈下量はより広い範囲に分布する. パラメータ $\beta^{(0)}, \gamma^{(0)}$ の值により, 時刻 $t$ における予測沈下量の $95 \%$ 信用区間がどのように変化するかを図-8に示す， $\phi_{i}$ の 事前確率密度の初期パラメータは任意に設定できるが, ベイズ学習の効率性を向上させるためには, 事前分布 は分散している方が望ましい. 本研究では, パラメータ 初期值として $\beta^{(0)}=0.5, \gamma^{(0)}=0.5$ を設定した。図-7 に示す結果より, これらの初期值を用いたケースは, 同 図に示す $4 つ の$ 計算ケースの中で, パラメータ值の事前 分布の分散がもっとも大きくなっている.

\section{(4) 3 次モデルの作成}

空港の供用後, 継続的モニタリングにより, 各平面 メッシュの地盤沈下量に関する情報を獲得できる.こ のようなモニタリング情報を用いて, 混合地盤沈下モ デルを更新する問題を考える。現時点においては，空

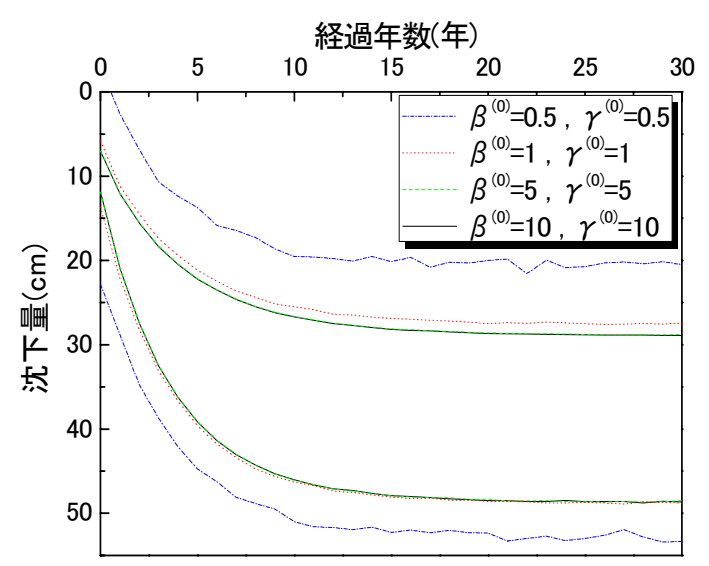

図-8 予測沈下量の $95 \%$ 信用区間

港が供用されておらず，モニタリング情報が蓄積され ていない. そこで, 各平面メッシュの地盤沈下量のモ ニタリング結果を仮想的に作成し，混合地盤沈下モデ ルのベイズ更新を試みる。いま, 空港の運営・管理中 の期間を，1) 初年度から 6 年度，2）6年度からそれ以 降の期間の 2 つに分割する. 供用開始後, 毎年定期的に 地盤沈下量がモニタリングされ, 供用開始後 5 年度の時 点に, 混合地盤沈下モデルをベイズ推計する問題を考 える. ついで, 6 年度以降においても, 毎年地盤沈下に 関するモニタリング情報が獲得できる。そこで，新し く得られたモニタリング情報を, それまでの年度に得 られたデータベースに加算し, 新しく更新されたデー タベースに基づいて, 混合地盤沈下モデルを毎年ベイ ズ更新する問題もとりあげる.

対象とする空港地盤には, 合計 528 個の平面メッシュ が存在する. 空港エプロン供用後 5 年後を想定し， 5 年 間のモニタリング情報を用いて混合地盤沈下モデルを 更新し， 6 年度以降の地盤沈下量を予測する問題を考え る.図-6には，528個の平面メッシュの中から，事例と して選択したメッシュ $(i=73)$ をとりあげ，1次モデル で作成したサンプルパス，2次モデルで求めた期待值パ スを示している。現時点では，モニタリング情報が存 在しないため，仮想的にモニタリング情報を与えるこ とにより，3次モデルをベイズ推計する. 現実の地盤沈 下量が当初想定した 2 次モデルの期待值パスより大きく なっても, 3 次モデルのベイズ推計により地盤沈下を子 測結果を適切に補正することができるかどうか確認す るために，図-6の○印で示すような仮想モニタリング 情報を想定した。ここで例示した地盤沈下過程は，期 待サンプルパスよりも下方に位置しており, 地盤沈下 量が期待值パスよりも大きくなっている. 対象とする 
表-4 混合地般沈下モデルの推計結果

\begin{tabular}{c|c|c|c|c}
\hline パラ & 期待值 & \multicolumn{2}{|c}{$95 \%$ 信用区間 } & $\begin{array}{c}\text { Geweke検 } \\
\text { メータ }\end{array}$ \\
& & \multicolumn{2}{|c|}{} & 定統計量 \\
\hline$\omega_{73}(1)$ & 0.553 & 0.518 & 0.589 & $-8.63 \mathrm{E}-02$ \\
$\omega_{73}(2)$ & 0.447 & 0.428 & 0.467 & $8.63 \mathrm{E}-02$ \\
$\phi_{73}$ & 2.76 & 0.66 & 7.41 & $-4.49 \mathrm{E}-02$ \\
\hline
\end{tabular}

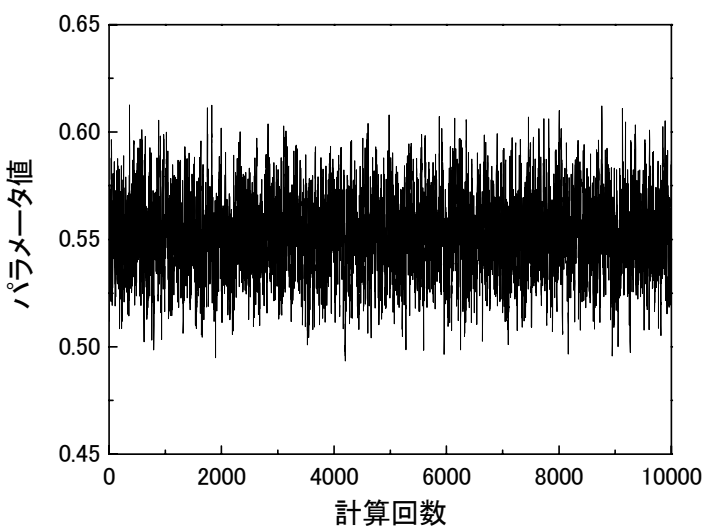

図-9 パラメータ $\omega_{73}(1)$ の収束過程

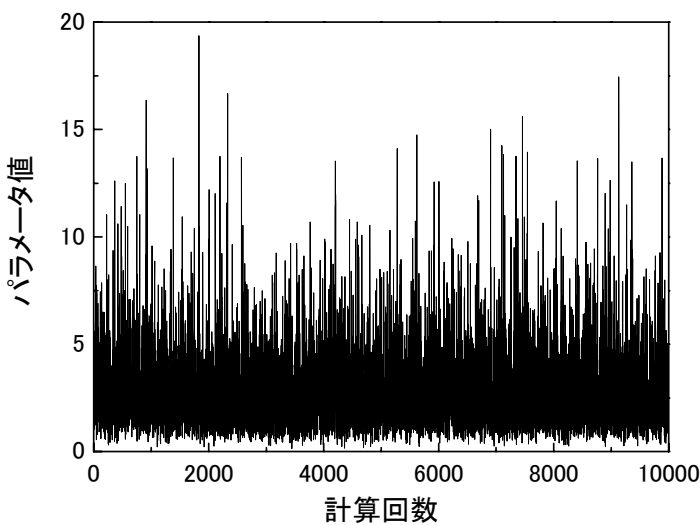

図-10 パラメータ $\phi_{73}$ の収束過程

メッシュの混合地盤沈下モデルは

$$
y_{73}^{t}=\sum_{k=1}^{2} \omega_{73}(k) f_{73}(t, k)+\varepsilon_{73}
$$

と表される.また， $k=1$ は図-6に示すサンプルパス $\alpha$ と, $k=2$ はサンプルパス $\beta$ に対応している.

さらに, 混合地盤沈下モデルの重みべクトル $\boldsymbol{\omega}_{i}$ の事 前確率密度関数として，2次モデルで採用したディリク レ分布と同一の分布を用いた。一方，確率誤差項 $\varepsilon_{i}$ の分 散パラメータ $\phi_{i}$ の事前確率密度関数は式 (12)のガンマ 分布に従い，ガンマ分布のパラメータを，6. (3) におけ る考察に基づいて, $\left(\beta^{(0)}, \gamma^{(0)}\right)=(0.5,0.5)$ と設定した.

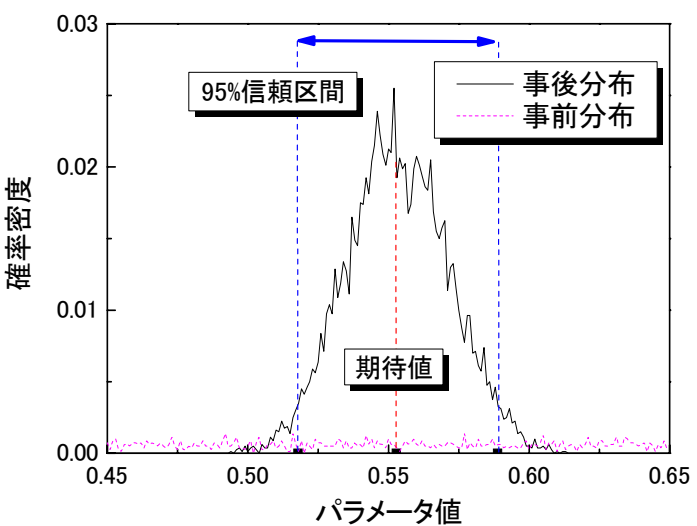

図-11 パラメータ $\omega_{73}(1)$ の確率分布

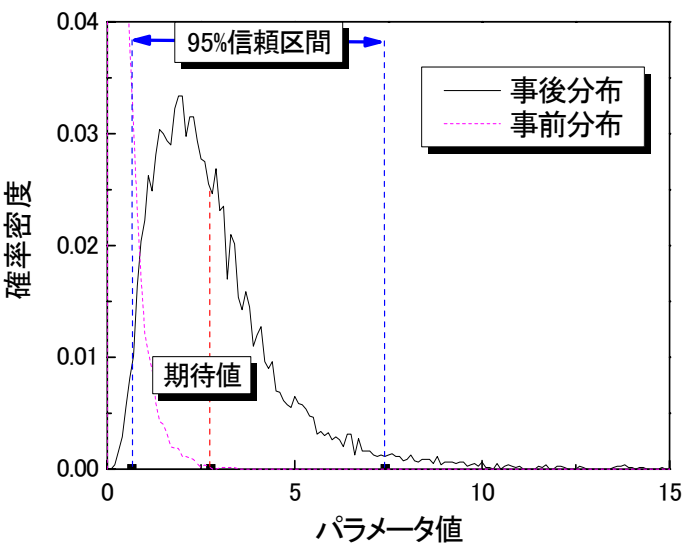

図-12 パラメータ $\phi_{73}$ の確率分布

また，収束判定のサンプル数は $\underline{n}=2,000, \bar{n}=10,000$ の合計 8,000 サンプルとした.

まず，供用開始後，5年間のモニタリング情報に基づ いて，混合地盤沈下モデルをべイズ推計する問題をと りあげる．表-4に，混合地盤沈下モデルの推計結果と して, 重み $\omega_{73}(1), \omega_{73}(2)$ と分散パラメータ $\phi_{73}$ の期待 值， $95 \%$ 信用区間，およびGeweke検定統計量 ${ }^{21)}$ を示 している. Geweke検定統計量は，MCMC 法によるサ ンプリング過程が定常状態に到達しているか否かを検

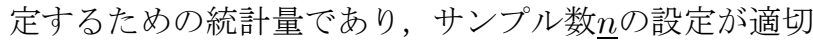
かどうかを検定するために用いられる. 推計結果より, 重みの合計は 1 となっており, 制約条件式(10)を満足 している. また, 重み $\omega_{73}(1)$ の期待值が大きくなって いるが，これは仮想モニタリング情報がサンプル平均 パスより上方に位置しているためであり，必然的な結 果といえる。重み $\omega_{73}(1)$ と分散 $\phi_{73}$ の収束過程を図-9, 図-10に, これら 2 つのパラメータの事後確率密度分布 を図-11，図-12に示寸．また，MH法を実施する際に， 


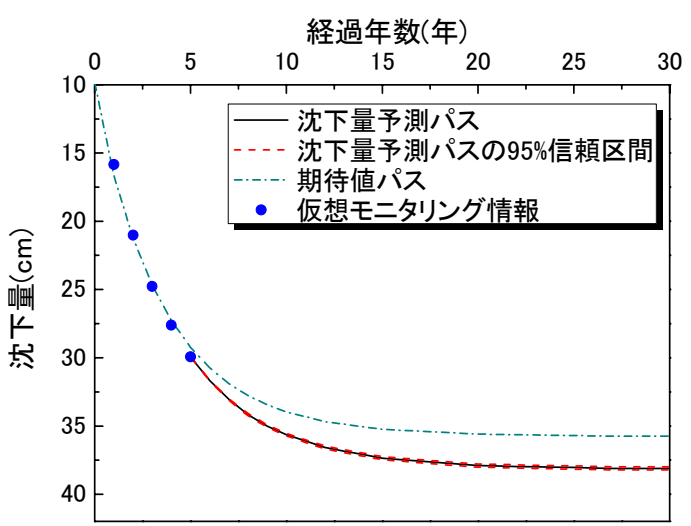

図-13 5 年度における沈下量予測結果

マルコフ連鎖が定常状態に到達するためのサンプル数 として $\underline{n}=2,000$ を設定したが, Geweke検定統計量の 絶対值はいずれも 1.96 を下回っており, 有意水準 $5 \%$ で 「定常状態に収束している」という仮説を棄却できない. 図-11，図-12には，これらのパラメーターの事前分布 も示しているが，ベイズ更新により混合地盤沈下モデ ルにおけるパラメータ分布の分散が小さくなっている.

つぎに， 5 年度にベイズ更新された混合地盤沈下モデ ルを用いて，6年度以降の地盤沈下パスを予測した結果 を図-13に示す，前述したように，地盤沈下過程の実績 パスとして，期待サンプルパスよりも沈下量が大きい パスを仮想的に設定している. したがって, 経過年数 30 年の時点での予測沈下量の期待值が $38.11 \mathrm{~cm}$ となり, 期待サンプルパスの $35.75 \mathrm{~cm}$ よりも大きくなっている. 供用後 30 年度における $95 \%$ 信用区間の下限は $37.99 \mathrm{~cm}$, 上限は $38.22 \mathrm{~cm}$ であり, ベイズ更新の結果, 混合地盤 沈下モデルの推計精度が向上し, より正確な地盤沈下 リスクの管理が可能になることが判明した.

さらに, 6 年度以降も, 継続してモニタリング情報が 蓄積され, 混合地盤沈下モデルを逐次ベイズ更新する問 題を考える. 再び，平面メッシュ $i=73$ に着目する. 同 メッシュでは, 図-6に示したように，6年度以降に○印 で示すようなモニタリング結果が追加されている。ここ で, 各年度に新しいモニタリング情報が得られる度に, 混合地盤沈下モデルが逐次ベイズ更新されると考える. さらに，更新された混合地盤沈下モデルを用いて，空 港供用後, 30 年度の地盤沈下量を予測した結果を表-5 に示している，同表には，当該年までのモニタリング 情報を用いてベイズ更新した混合地盤沈下モデルを用 いて, 供用後 30 年度の地盤沈下量の予測値 (期待値) と $95 \%$ 信用区間の上・下限值を記載している。なお， 30 年時点の仮想モニタリング情報 (沈下量) は $39.09 \mathrm{~cm}$ で
表-5 地盤沈下量の予測結果 (メッシュ $i=73$ )

\begin{tabular}{c|c|c|c|c}
\hline 当該年 & $\begin{array}{c}30 \text { 年時点の } \\
\text { 沈下量予測值 }\end{array}$ & \multicolumn{2}{|c|}{$95 \%$ 信用区間 } & $\begin{array}{c}\text { 信用区間 } \\
\text { の幅 }\end{array}$ \\
\hline 5 年 & 38.109 & 37.990 & 38.224 & 0.234 \\
6 年 & 38.209 & 38.139 & 38.279 & 0.140 \\
7 年 & 38.218 & 38.174 & 38.263 & 0.089 \\
8 年 & 38.226 & 38.199 & 38.254 & 0.055 \\
9 年 & 38.439 & 38.419 & 38.457 & 0.038 \\
10 年 & 38.151 & 38.140 & 38.163 & 0.023 \\
15 年 & 38.115 & 38.114 & 38.116 & 0.002 \\
20 年 & 38.477 & 38.477 & 38.477 & 0.000 \\
25 年 & 39.046 & 39.046 & 39.046 & 0.000 \\
\hline
\end{tabular}

注) 30 年時点における仮想モニタリング情報 (沈下量) は $39.09 \mathrm{~cm}$ である.

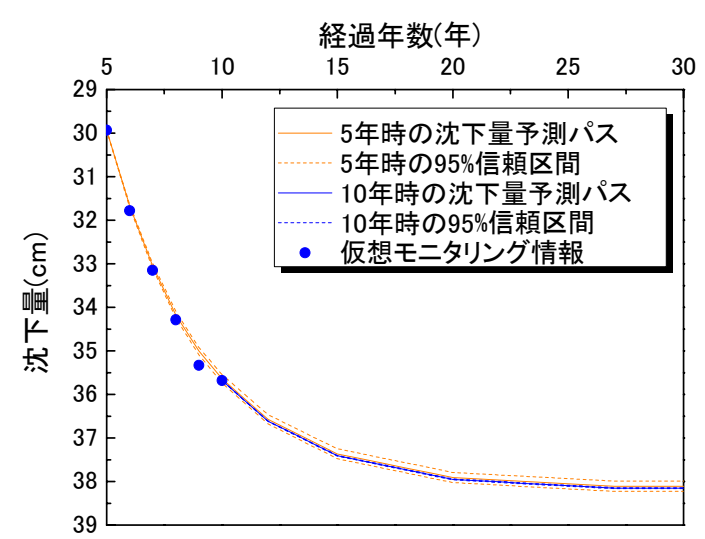

図-14 10 年度における予測結果

ある. ベイズ更新の結果を比較すると, 情報の蓄積と ともに, 期待值パスが若干修正されるとともに, 信用 区間の幅が狭まっている．このことからべイズ更新に より推計精度が高まっていることが理解できる。なお, 図-14には，10年時点までモニタリング情報が蓄積さ れた場合をとりあげ，この時点において予測した 10 年 度以降の地盤沈下量の期待值パスと $95 \%$ 信用域を示し ている. 5 年時点で予測したサンプルパスの信用域と, 10 年時点におけるサンプルパスの信用域を比較するこ とにより，ベイズ更新を通じて混合地盤沈下モデルの 信用性が向上していることを視覚的に確認寸ることが できる。

つぎに，予測しえない急激な沈下が観測された場合 のベイズ更新結果を検証する. 図-15にその場合の仮想 モニタリング情報を示す． 5 年まではこれまでと同様の 沈下量が観測され，6年度に急激な沈下の発生を想定し ている. 図中の青いプロットはこれまでのモニタリング 情報 (ケース 1) であるが, 赤いプロットが今回のケー ス (ケース 2 ) である。この情報に基づいてベイズ更新 


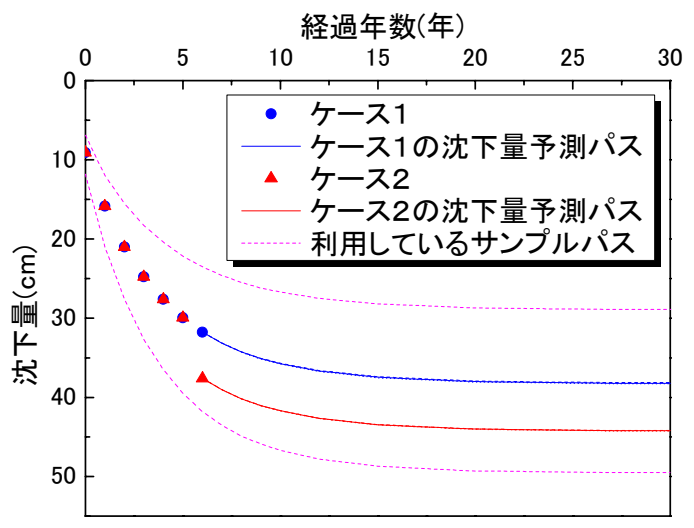

図-15＼cjkstart急激な変化における予測結果

を行った結果 (沈下パス) を同図に併せて示している. 沈下量はかなり大きくなるが，新規情報を反映したべ イズ更新がなされていること，これまでと同様に沈下 が 12 年程度で収束傾向を示していることを確認できる. これは，今回与えた急激な沈下量が，利用しているサ ンプルパスの上・下限值内に収まっていたことが要因で ある。実際に計測される地盤沈下過程の定性的な特性 が許容範囲内にあれば，重みパラメータを修正するこ とにより, その後の沈下過程を表現できる. 地盤沈下過 程の実測值が，1次モデルによる予測結果による適用可 能性の範囲内に収まっているかどうかに関する検討方 法に関しては，6. (5)でとりあげる．表-6には，重み パラメータの推計結果を示している. 表-4 と比較して, サンプルパスの重みパラメータが補正され, $\omega_{73}(2)$ の 值が大きくなっていることが確認できる．したがって， 実用化に際しては，サンプルパスの上・下限值の範囲 を広めに設定しておくことが有効であると考えられる.

\section{(5) モデルの適用範囲の検証}

本研究で提案したハイブリッド型地盤沈下モデルを 用いることにより，1次モデルが有効であるという前提 の下で, 地盤沈下の継続的モニタリングにより, 地盤沈 下予測の精度を恒常的に改善することができる。しか し，混合沈下モデルによる予測結果と現実の観測值の 間には, 推計残差が存在する。このような推計残差と して, ランダムな推計残差とシステム的な推計残差が 考えられる. ランダムな推計残差に関しては, 混合地 盤沈下モデルをベイズ更新することにより, 地盤沈下 過程の推計精度を向上することが可能である。しかし， システム的な推計残差が発生する場合, ハイブリッド 型地盤沈下モデルの適用可能性を吟味することが必要 となる.たとえば，図-16の事例では，仮想的な沈下過 程の1例を示しているが, 仮にこのようなモニタリング
表-6 予期しえない沈下に対する補正結果

\begin{tabular}{|c|c|c|c|c|}
\hline パラ & & \multicolumn{2}{|c|}{ 95\%信用区間 } & \\
\hline$\omega_{73}(1)$ & 0 & 0462 & 0482 & $210 \mathrm{~F}_{\Omega} \mathrm{O} 2$ \\
\hline$\omega_{73}(2)$ & 0.528 & 0.518 & 0.538 & $-2.10 \mathrm{E}-02$ \\
\hline$\phi_{73}$ & 61.34 & 18.55 & 133.40 & $-1.70 \mathrm{E}-02$ \\
\hline
\end{tabular}

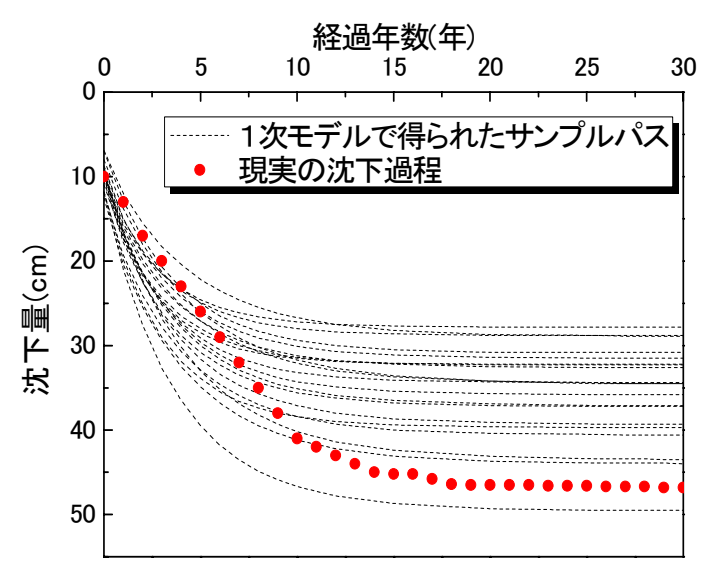

図-16 混合地盤沈下モデルのシステム的誤差

情報が得られたとした場合, モニタリング結果と 1 次モ デルで想定した沈下過程の間に乘離が発生しているこ とを疑うことが必要となる. 混合地盤沈下モデルは，1 次モデルで得られたサンプルパスの線形結合で表現さ れるため, ベイズ更新を通じても混合地盤沈下モデル のシステム的な推計誤差を補正できない.

混合地盤沈下モデルにシステム的推計残差が存在す るか否かを統計的に仮説検定する方法論を提案する.い ま, 時点 $t=T$ までのモニタリング情報 $\overline{\boldsymbol{y}}_{i}^{0, T}=\left\{\bar{y}_{i}^{t}: \underline{t}=\right.$ $1, \cdots, T\}$ を用いて混合地盤沈下モデル,

$$
y_{i}^{t}=\sum_{k=1}^{K} \omega_{i}(k) f_{i}(t, k)+\varepsilon_{i}
$$

が得られたと考える。ただし, 混合地盤沈下モデルの 重夕係数 $\omega_{i}(k)$ として, ベイズ更新後のサンプル平均パ スの重み $\tilde{\omega}_{i}(k)$ を用いる. この時, 時点 $\underline{t}(\leq T)$ における 残差は,

$$
\xi_{i}^{\underline{t}}=\bar{y}_{i}^{\underline{t}}-\sum_{k=1}^{K} \tilde{\omega}_{i}(k) f_{i}(\underline{t}, k)
$$

と表すことができる。したがって, システム的推計残 差の有無は,

$$
\xi_{i}^{\underline{t}}=\rho_{i} \xi_{i}^{\underline{t}-1}+\varpi_{i}^{t}
$$

において，1階の自己相関係数 $\rho$ を推計することで判別 することができる.ただし， $\varpi_{i}^{t} \sim \mathcal{N}\left(0, \vartheta_{i}^{2}\right)$ はホワイト ノイズである.このとき, システム的推計残差が存在 
するか否かを検討する仮説検定モデルを，

$$
\left\{\begin{array}{l}
H^{0}: \rho_{i}=0 \\
H^{1}: \rho_{i} \neq 0
\end{array}\right.
$$

と定式化できる。いま， $\rho$ の事前確率密度関数が無情報 事前分布 (定数), $\psi_{i}=\vartheta_{i}^{-2}$ の事前確率密度関数がガン マ分布 $\mathcal{G}\left(\zeta_{i}, \eta_{i}\right)$ に従うと考える. この時, $\rho$ の事後確率 密度関数 $\pi\left(\rho \mid \overline{\boldsymbol{y}}_{i}^{0, T}\right)$ は,

$$
\begin{aligned}
& \pi\left(\rho \mid \overline{\boldsymbol{y}}_{i}^{0, T}\right) \propto \phi_{i}^{\zeta_{i}+(T-1) / 2} \\
& \exp \left[-\psi_{i}\left\{\eta_{i}+\frac{1}{2} \sum_{\underline{t}=1}^{T}\left(\xi_{i}^{\underline{t}}-\rho \xi_{i}^{\underline{t}-1}\right)^{2}\right\}\right]
\end{aligned}
$$

と表すことができる，さらに，MCMC 法により，パラ メータ $\rho$ に関するサンプリングを行い，式(37a),(37b) と同様にパラメータ $\rho$ の $100(1-2 \delta) \%$ 信用区間を定義す る. $100(1-2 \delta) \%$ 信用区間に $\rho=0$ が含まれなければ, 有意水準 $100(1-2 \delta) \%$ で $\rho=0$ という仮説を棄却でき る. 現時点において, 対象地盤における地盤沈下モニ タリングデータが蓄積されておうらず，本研究で用いた 1 次モデルの適用範囲を検討できる段階ではない。しか し, 現実の地盤沈下過程の観測結果, 仮説 $H^{0}$ が棄却さ れた場合, 1 次モデルの信頼性に問題が生じているわけ であり，地盤モデル，あるいは圧密沈下モデル自体を 再検討しなければならない。

\section{(6) 舗装劣化予測への展望}

本研究は, 空港舗装アセットマネジメントを主たる 目的として，特に海上空港を具体的な検討対象として いる. 海上空港の舗装の劣化予測を行うに際して, 地盤 沈下がその劣化過程に及ぼす影響は極めて大きく, 本 研究では地盤沈下モデルの開発に焦点を絞った。しか し，空港舖装アセットマネジメントを実践するために は, 地盤沈下モデルと連動した舗装劣化モデルの開発 （点から面への拡張）が不可欠である.

空港のコンクリート舗装の劣化予測に関して，すで に下村ら ${ }^{12)}$ は不同沈下を考慮した疲労度設計手法に基 づき，コンクリート舗装版の累積疲労度を算定するこ とにより, コンクリート舗装の劣化過程を予測し, 維 持補修戦略を検討する方法を提案している。この手法 ではコンクリート舖装版の勾配や目地位置を考慮した 面的な不同沈下を算出することができる．また，舗装 版内の応力を算出する過程で, 地盤の不同沈下, 航空 機の輪荷重およびコンクリート版上下面の温度差の影 響が考慮されており，これらの影響因子を確率変数と して扱うことで複数の舗装劣化パス（舗装健全度の時 系列）を記述することができる。したがって，これらの 複数の舗装劣化パスの統計的規則性をマルコフ劣化八 ザードモデルを用いて記述することが可能である。さ らに, 本研究と同様に, 運営段階で蓄積されるモニタリ
ング情報（地盤沈下量, 舗装健全度など）を利用して, 舗装劣化パスを更新する必要性が生じるが，この点に ついてもマルコフ劣化ハザードモデルのベイズ更新モ デルを援用して開発することができる20)．ただし，こ れらの舗装劣化予測全体を包摂したようなハイブリッ ド型劣化予測に関しては, 本研究の域を超えるために, 別の機会に発表したいと考える.

さらに, 空港舗装の補修計画を立案することも重要 な課題であり, 舖装劣化予測と連動したライフサイク ル費用評価手法も開発しなければならない。特に，本 研究で示した海上空港のように, 今後社会基盤施設の 維持管理業務がPFI事業として民間に委託されるケー スが増加すると予想される，そのような場合には，劣 化過程に介在する不確実性に起因するライフサイクル 費用リスク（費用変動）を把握しておくことが極めて 重要である. 特にPFI事業では, 契約終了時点で達成 すべき施設の健全状態が定められることになる．した がって, 状態依存および地盤沈下量依存に加え, 時間 依存を考慮したマルコフ意思決定モデルを解く必要性 が生じる．著者らは，この問題に対する分析にも着手 しており，この点についても，別途報告を行いたいと 考えている.

\section{7. おわりに}

本研究では, 空港施設のアセットマネジメントにお いて重要な課題となる地盤沈下の継続的モニタリング とモニタリング情報を用いた地盤沈下予測結果をべイ ズ更新するための方法論の提案を試みた。具体的には 不同沈下を考慮した 1 次元圧密モデルを用いて, 地盤沈 下過程に関するサンプルパスを作成するとともに，サ ンプルパスを荷重平均した混合地盤沈下モデルを作成 した.さらに空港の供用開始後，地盤沈下量を継続的 にモニタリングすることにより, 混合地盤沈下モデル を MCMC (マルコフ連鎖モンテカルロ) 法を用いて心゙ イズ更新する方法論を提案した。ささらに空港施設の地 盤沈下予測管理問題への適用事例を通じて本研究で提 案した方法論の有効性に関して実証的に検証した。し かし，本研究で提案したベイズ更新モデルの適用可能 性を向上するためには, 以下のような研究課題が残さ れている. 第 1 に, 本研究の適用事例は, 現時点におい て空港整備事業が開始された段階である。したがって, 現時点においてモニタリング情報が入手可能ではない. したがって，適用事例では，モニタリング情報を人工 的に作成することにより混合地盤沈下モデルのべイズ 更新を試みた。 今後, 空港地盤の沈下過程を継続的に モニタリングすることにより, 混合地盤沈下モデルの ベイズ更新の有効性を，現実のモニタリング情報を用 
いて検証することが必要である，第 2 に，空港舗装マネ ジメントにおいて地盤沈下予測管理は重要な検討課題 ではあるが，舗装マネジメントを実施するためには空 港舗装の劣化・損傷過程を管理することが必要である. そのためには, 地盤沈下に伴い空港舗装の劣化・損傷が

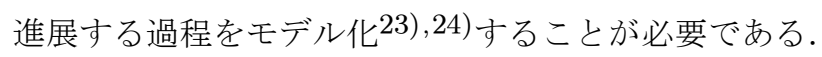
第 3 に, 本研究で提案した方法論は, 1 次モデルが有効 であるという範囲内において，適用可能である．6. (5) では, 混合地盤沈下モデルの推計残差を用いて, 1次モ デルの有効性を検討する方法論を提案した。しかし，推 計残差の系列相関が大きく，1次モデルの有効性に限界 があることが判明した場合，本研究で提案した方法論 を用いて地盤沈下予測を継続的に実施することには問 題がある. この場合, 1 次モデルにさかのぼり, モデル の仮定や前提条件の再吟味，あるいはモデルの再構築 が必要となることは言うまでもない。このような 1 次 モデルのフォローアップに関しては, 今後に残された 大きな研究課題である. 第 4 に, 本研究で提案したベイ ズ更新モデルは，モニタリング情報に基づいて設計段 階における予測結果をベイズ更新するための方法論を 提案したものである. このようなべイズ更新モデルは, 地盤沈下予測管理以外の幅広い問題に対して適用でき る可能性を持っている. 今後, ベイズ更新モデルの方 法論の有効性を空港舗装以外の土木施設のアセットマ ネジメント問題に対して検証することが必要である.

なお, 本研究の一部は文部科学省科学技術調整振興 費「若手研究者の自立的研究環境整備促進」事業によ り大阪大学大学院工学研究科グローバル若手研究者フ ロンティア研究拠点において実施された.

\section{参考文献}

1) 松尾稔 : 地盤工学一信頼性設計の理念と実際一, 技報堂 出版, 1984.

2) Tang, W.H.: Probabilistic evaluation of penetration resistance, Proc. of ASCE, Vol.105, GT10, pp.11731191, 1979.

3) 奥村樹郎, 土田孝：土質定数のばらつきを考慮した不 同沈下の推計, 港湾技術研究所報告, 第 20 巻, 第 3 号, pp.131-168, 1981.

4) 久楽勝行, 護摩堂満, 竹内辰典 : 軟弱地盤上の不同沈下の 実態とその予測，土木技術資料，25-12，pp.14-21，1983.

5) 土田孝, 小野憲司 : 数值シミュレーションによる不同沈 下の予測とその空港舗装設計一の適用, 港湾技術研究所 報告，第 27 巻，第 4 号, pp.123-200, 1988.

6) Yuan, J. and Mooney, M.A.: Development of adaptive performance models for the Oklahoma airfield pave- ment management system, TRB 2003 Annual Meeting Nov.15, pp.1-24, 2002.

7) Pavement Management System: Advisory Circular, Federal Aviation Administration, AC No.150/5380-7, pp.1-8, 1988.

8) Mishalani, R. and Madanat S.: Computation of infrastructure transition probabilities using stochastic duration models, ASCE, Journal of Infrastructure Systems, Vol.8, No.4, pp.139-148, 2002.

9) Shin, H.C. and Madanat, S.M.: Development of a stochastic model of pavement distress initation, 土木 学会論文集, No.744/IV-61, pp.61-67, 2003.

10）津田尚扸, 貝戸清之, 青木一也, 小林潔司: 橋梁劣化予 測のためのマルコフ推移確率の推計, 土木学会論文集, No.801/I-63, pp.68-82, 2005.

11) 青木一也, 山本浩司, 津田尚扸, 小林潔司: 多段階ワイブ ル劣化ハザードモデル, 土木学会論文集, No.798/VI-68, pp.125-136, 2005.

12) 下村泰造, 西澤辰男, 吉永清人, 福岡知久: 疲労度設計 法を用いた空港コンクリート舗装の維持管理手法の検討, 土木学会舗装工学論文集, 第 12 巻, pp.211-218, 2007.

13) Yoshikuni, H., Kusakabe, O., Hirao, T. and Ikegami, S.: Elasto-viscous modeling of time-dependent behavior of clay, Proceedings of 13th ICSMFE, Vol.1, pp.417-420, 1994.

14) Terzaghi, K.: Erdbaumechanik, pp.140-152, F. Deuticke, 1925.

15) Jeffreys, H.: The Theory of Probability, Oxford University Press, 1961.

16) Gilks, W.R. and Wild, P.: Adaptive rejection sampling for Gibbs sampling, Applied Statistics, Vol.41, pp.337-348, 1992.

17) Ibrahim, J.G., Ming-Hui, C. and Sinha, D.: Bayesian Survival Analysis, Springer Series in Statistics, 2001.

18) 和合肇: ベイズ計量経済分析, マルコフ連鎖モンテカル ロ法とその応用，東洋経済新報社，2005.

19）伊庭幸人：計算統計学のフロンティアー計算統計 II, マ ルコフ連鎖モンテカルロ法とその周辺, 岩波書店, 2005.

20) 貝戸清之, 小林潔司: マルコフ劣化ハザードモデルのベイ ズ推定，土木学会論文集 A, Vol.63, No.2, pp.336-355, 2007.

21) Geweke, J.: Evaluating the accuracy of samplingbased approaches to the calculation of posterior moments, Bayesian Statistics, Vol.4, pp.169-193, Oxford University Press, 1996.

22) Chib, S.: Marginal likelihood from Gibbs output, Journal of the American Statistical Association, Vol.90, pp.1313-1321, 1995.

23) 小梁川雅, 野田悦郎, 伊藤正秀 : 供用履歴を受けたコン クリート舗装の疲労特性に関する研究, 土木学会舗装工 学論文集, 第 9 巻, pp.149-156, 2004.

24）西澤辰男，松野三朗：コンクリート舗装の構造解析にお ける有限要素法の適用性について, 土木学会論文報告集, 第338号, pp.207-215, 1983.

(2007.12.5 受付) 


\section{A HYBRID GROUND CONSOLIDATION MODEL FOR AIRPORT PAVEMENT MANAGEMENT}

Taizo SHIMOMURA, Kengo OBAMA, Kiyoyuki KAITO and Kiyoshi KOBAYASHI

The estimation of consolidation processes is an important subject for the asset management of airport facilities. In the planning and design stage, there exist many uncertainties in geotechnical conditions, it is impossible to estimate the ground consolidation process by deterministic methods. In this paper, the sets of sample paths designating ground consolidation processes are generated by use of a one-directional consolidation model incorporating uneven ground settlement. Given the sample paths, the mixed consolidation model is presented to describe the probabilistic structure behind the sample paths. The mixed model can be updated by the Bayesian methods based upon the monitoring data. Through a case study, this paper verified the validity of the proposed method and illustrated its possible appllication and future works. 